University of Wollongong

Research Online

Faculty of Engineering and Information

Faculty of Engineering and Information

Sciences - Papers: Part A

Sciences

$1-1-2013$

\title{
Influence of rock depth on seismic site classification for shallow bedrock regions
}

P Anbazhagan

anbu@uow.edu.au

M. Neaz Sheikh

University of Wollongong, msheikh@uow.edu.au

Aditya Parihar

Indian Institute of Science

Follow this and additional works at: https://ro.uow.edu.au/eispapers

Part of the Engineering Commons, and the Science and Technology Studies Commons

Research Online is the open access institutional repository for the University of Wollongong. For further information contact the UOW Library: research-pubs@uow.edu.au 


\title{
Influence of rock depth on seismic site classification for shallow bedrock regions
}

\begin{abstract}
Seismic site classifications are used to represent site effects for estimating hazard parameters (response spectral ordinates) at the soil surface. Seismic site classifications have generally been carried out using average shear wave velocity and/or standard penetration test $n$-values of top 30-m soil layers, according to the recommendations of the National Earthquake Hazards Reduction Program (NEHRP) or the International Building Code (IBC). The site classification system in the NEHRP and the IBC is based on the studies carried out in the United States where soil layers extend up to several hundred meters before reaching any distinct soil-bedrock interface and may not be directly applicable to other regions, especially in regions having shallow geological deposits. This paper investigates the influence of rock depth on site classes based on the recommendations of the NEHRP and the IBC. For this study, soil sites having a wide range of average shear wave velocities (or standard penetration test n-values) have been collected from different parts of Australia, China, and India. Shear wave velocities of rock layers underneath soil layers have also been collected at depths from a few meters to $180 \mathrm{~m}$. It is shown that a site classification system based on the top 30-m soil layers often represents stiffer site classes for soil sites having shallow rock depths (rock depths less than $25 \mathrm{~m}$ from the soil surface). A new site classification system based on average soil thickness up to engineering bedrock has been proposed herein, which is considered more representative for soil sites in shallow bedrock regions. It has been observed that response spectral ordinates, amplification factors, and site periods estimated using one-dimensional shear wave analysis considering the depth of engineering bedrock are different from those obtained considering top 30-m soil layers. DOI: 10.1061/(ASCE)NH.1527-6996.0000088. (C) 2013 American Society of Civil Engineers.
\end{abstract}

\section{Keywords}

shallow, classification, site, regions, seismic, bedrock, depth, rock, influence

Disciplines

Engineering | Science and Technology Studies

\section{Publication Details}

Anbazhagan, p., Sheikh, M. Neaz. \& Parihar, A. (2013). Influence of rock depth on seismic site classification for shallow bedrock regions. Natural Hazards Review, 14 (2), 108-121. 


\title{
Influence of Rock Depth on Seismic Site Classification for Shallow Bedrock Regions
}

\author{
P. Anbazhagan, M.ASCE${ }^{1}$; M. Neaz Sheikh²; and Aditya Parihar ${ }^{3}$
}

\begin{abstract}
Seismic site classifications are used to represent site effects for estimating hazard parameters (response spectral ordinates) at the soil surface. Seismic site classifications have generally been carried out using average shear wave velocity and/or standard penetration test $n$-values of top 30-m soil layers, according to the recommendations of the National Earthquake Hazards Reduction Program (NEHRP) or the International Building Code (IBC). The site classification system in the NEHRP and the IBC is based on the studies carried out in the United States where soil layers extend up to several hundred meters before reaching any distinct soil-bedrock interface and may not be directly applicable to other regions, especially in regions having shallow geological deposits. This paper investigates the influence of rock depth on site classes based on the recommendations of the NEHRP and the IBC. For this study, soil sites having a wide range of average shear wave velocities (or standard penetration test $n$-values) have been collected from different parts of Australia, China, and India. Shear wave velocities of rock layers underneath soil layers have also been collected at depths from a few meters to $180 \mathrm{~m}$. It is shown that a site classification system based on the top 30-m soil layers often represents stiffer site classes for soil sites having shallow rock depths (rock depths less than $25 \mathrm{~m}$ from the soil surface). A new site classification system based on average soil thickness up to engineering bedrock has been proposed herein, which is considered more representative for soil sites in shallow bedrock regions. It has been observed that response spectral ordinates, amplification factors, and site periods estimated using one-dimensional shear wave analysis considering the depth of engineering bedrock are different from those obtained considering top 30-m soil layers. DOI: 10.1061/(ASCE)NH.1527-6996.0000088. @ 2013 American Society of Civil Engineers.
\end{abstract}

CE Database subject headings: Seismic effects; Shear waves; Wave velocity; Bedrock.

Author keywords: Seismic; Site classification; Soil depth; Shear wave velocity; Site response; Amplification.

\section{Introduction}

Soil condition modifies ground motion and in many cases results in greater amplitude of motion together with a change in frequency content and duration of ground motion. Site-specific ground response analysis aims at determining the effect of local soil conditions on site response (e.g., amplification of seismic shear waves, effect on frequency content, and duration of ground motion). Estimation of the earthquake response spectra with due consideration to the local soil site effects is very important for the design of new structures and performance assessment of existing structures (Tsang et al. 2006; Chandler et al. 2002). The response at the surface of soil deposits is dependent mainly on the frequency content and amplitude of ground motion at bedrock, and the geometry and material properties of the soil layers above the bedrock. Site-specific response parameters (response spectral acceleration, velocity, and displacement) are directly or indirectly quantified and represented by a number of researchers as part of seismic microzonation studies. In such microzonation studies and also in design codes worldwide, site

\footnotetext{
${ }^{1}$ Assistant Professor, Dept. of Civil Engineering, Indian Institute of Science, Bangalore 5600012, India (corresponding author). E-mail: anbazhagan2005@gmail.com

${ }^{2}$ Senior Lecturer, School of Civil, Mining and Environmental Engineering, Univ. of Wollongong, Wollongong, NSW 2500, Australia.

${ }^{3}$ Research Scholar, Dept. of Civil Engineering, Indian Institute of Science, Bangalore 5600012, India.

Note. This manuscript was submitted on February 19, 2011; approved on July 23, 2012; published online on July 26, 2012. Discussion period open until October 1, 2013; separate discussions must be submitted for individual papers. This paper is part of the Natural Hazards Review, Vol. 14, No. 2, May 1, 2013. @ASCE, ISSN 1527-6988/2013/2-108-121/\$25.00.
}

effects are accounted for in the designation of seismic site classes. Although several methods for seismic site classifications have been recommended in design codes, most popular methods are those that consider borelogs with standard penetration test $n$-values (SPT-N) and shear wave velocities (SWVs) from spectral analysis of surface waves (SASW) and multichannel analysis of surface waves (MASW) (Anbazhagan and Sitharam 2008a). Most of the seismic site classification methods consider average values of SWV or SPT$\mathrm{N}$ of top 30-m soil layers, because of direct correlation with the method proposed by the National Earthquake Hazards Reduction Program (NEHRP) [Building Seismic Safety Council (BSSC) 2001] and the International Building Code (IBC) [International Code Council (ICC) 2006]. This has also been widely adopted in seismic microzonation studies (Anbazhagan and Sitharam 2008b; Anbazhagan et al. 2010). These site classification schemes are then combined with a probabilistic approach to estimate the surface level hazard response parameters (Raghu Kanth and Iyengar 2007).

Despite their wide use, the seismic site classification schemes considering top 30-m soil layers are under significant research scrutiny (Lee et al. 1995; Rodriguez-Marek et al. 2001; Kokusho and Sato 2008; Anbazhagan et al. 2011b). The applicability of such methods especially in shallow bedrock regions needs further investigation. Shallow bedrocks are more common in the most seismically vulnerable regions, where a distinct soil-bedrock interface can be observed within several meter depth of soil layers. However, in the high seismicity regions of the western United States where the first site classification schemes originated, distinct soilbedrock interface may not be evident even under several hundredmeter depth of soil layers. Considering the important differences between shallow bedrock regions and regions without a distinct soil-bedrock interface (in high seismic zones), when proposing site 
amplification parameters for regions with shallow bedrock depth, Tsang et al. (2006) recommends against adopting average SWVs for top 30-m soil layers $\left(V_{s, 30}\right)$.

In this study, for the assessment of site response, a suite of SPT-N and SWV data are collected from Australia, China, and India. First, these soil sites are analyzed based on top 30-m soil depths, according to the seismic site classification system recommended in the IBC (ICC 2006) and NEHRP (BSSC 2001). Second, a site classification scheme has been carried out considering soil layers up to the depth of weathered rock layer. Site classification of the soil sites has further been carried out by considering the depth of engineering rock. Shear wave velocity (SWV) of $700 \pm 60 \mathrm{~m} / \mathrm{s}$ is considered as the signature of engineering rock (Anbazhagan and Sitharam 2009b). It has been observed that site classes of the soil sites considering top 30-m soil layers without considering depth of engineering-rock layers may lead to stiffer site classes for sites having engineering-rock depth less than $25 \mathrm{~m}$ and softer site classes for sites having engineering-rock depth greater than $35 \mathrm{~m}$. A new classification scheme has been proposed herein considering thickness and average stiffness of the soil layers up to engineering rock, rather than average SWVs (or SPT-N values) of top 30-m soil layers. One-dimensional site response analyses using recorded and simulated earthquake ground motions have also showed important differences in response spectral ordinates even when similar average shear wave velocities of soil sites are assumed.

\section{Local Soil Conditions and Seismic Site Effects}

The damaging effects of local soil conditions have been evident in recent earthquakes around the world. Even earthquakes of moderate magnitude can cause severe damage to infrastructure, incurring significant economic loss and even loss of lives, if ground motion is amplified several times by local soil deposits. The 1989 Newcastle earthquake in Australia can be considered as one of many examples where significant damage and deaths were observed from site amplification where the magnitude of the earthquake was only 5.6 [Institution of Engineers Australia (IEA) 1990] The correlation between local soil condition and site amplification or building damage can be found even in studies carried out several decades ago.
In Fig. 1(a), the correlation between ratios of shear wave velocity of soil to rock and amplification magnitudes are shown (following Shima 1978). In Fig. 1(b), the damage intensity versus depth of soil sites for different story buildings is shown (following Seed et al. 1972).

It is evident from recent damaging earthquakes that geotechnical properties of local soils play a major role in site amplification and hence damage to infrastructure. Many seismic microzonation studies are started with subsurface geotechnical data profile modeling and seismic site characterization (Sitharam and Anbazhagan 2008). Literature review on this revealed that seismic site classifications for seismic microzonation studies are often carried out based on the IBC (ICC 2006) and NEHRP (BSSC 2001) recommendations in shallow bedrock regions, including Australia, China, and India. In these regions, many cities encountered rock depth at a few meters to several meters from the surface of the soil sites. Hence adopting a 30$\mathrm{m}$ based site classification may result in erroneous site classification and erroneous seismic design response spectral parameters (Tsang et al. 2006). To highlight these aspects, in this study, site-specific geotechnical data (in the form of SPT-N or SWV) for soil sites with depths up to engineering rock have been used based on the experimental results and the published data from the literature. These data contain drilled boreholes with SPT-N and SWV profiles. The SWV of $330 \pm 30$ and $760 \pm 60 \mathrm{~m} / \mathrm{s}$ (SPT-N value of 50 for rebound and 100 for no penetration) are considered weathered rock and engineering rock, respectively, based on the recommendations of Anbazhagan and Sitharam (2009a).

\section{Seismic Site Classification}

Local site conditions play a dominant role in damage distribution as well as in the recorded strong ground motion amplitudes (Roca et al. 2006). Geotechnical characteristics of soil deposits play an important role in the modification of seismic ground motion generally termed the local site effects. Site condition of individual soil sites based on SWV is a more direct indicator of local site effects. Site response studies require information of shear stiffness (correlated with SWV) of the soil column (Borcherdt 1994). The site classes in most design codes are defined in terms of SWV up to a depth of $30 \mathrm{~m}$ $\left(V_{s, 30}\right)$. If measurement of SWV up to $30 \mathrm{~m}$ is not feasible, SPT-N or

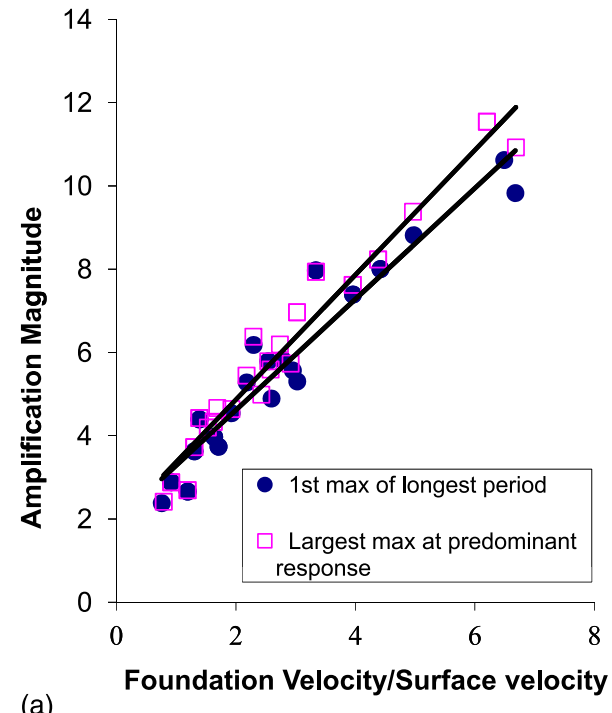

(a)

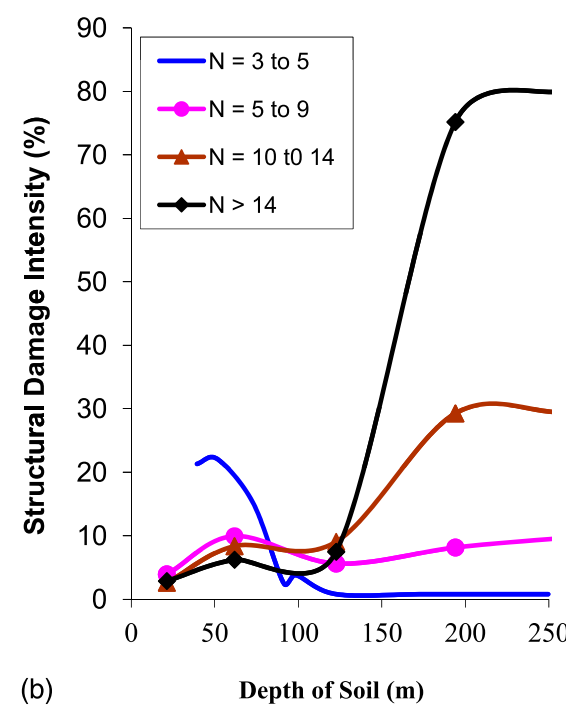

Fig. 1. (a) Amplification magnitude as a function of foundation/surface velocity (adapted from Shima 1978); (b) structural damage intensity as a function of soil depth, $N=$ number of building stories (adapted from Seed et al. 1972) 
undrained shear strength $\left(S_{u}\right)$ can be used (Borcherdt 1994). SWV can be directly measured in field tests or can be estimated from existing correlations between values of SPT-N and SWVs (Hasancebi and Ulusay 2006). A number of correlations are available between SPT-N and SWV; hence, a suitable correlation can be used based on the regional soil types (Anbazhagan et al. 2012). Kokusho (2008) highlighted that the current practice of averaging the SWV of top 30-m soil layers does not correlate well with amplification factors. He used acceleration recorded in KiK-net downhole arrays and considered a base layer where a downhole seismometer was installed. Base layer velocities $\left(V_{s, b}\right)$ ranging from 400 to $3000 \mathrm{~m} / \mathrm{s}$ at depths from 100 to $300 \mathrm{~m}$ were considered in the study. The author concluded that the ratio of the base layer velocity to the average shear wave velocity of soil layers over the base layer $\left(V_{s, b} / V_{s}\right)$ is well correlated with the amplification factor compared with the ratio of base layer velocity to the average of the top 30-m soil SWVs $\left(V_{s, b} / V_{s, 30}\right)$. It is noted that soil-bedrock interface can be encountered even within several-meter soil depths in shallow bedrock regions (Tsang et al. 2006).

Seismic ground response characteristics, defined generally as site effects, are incorporated in modern seismic design code provisions in many countries. However, the definitions of site classes in different codes are not consistent. Table 1 shows the summary of site classes adopted in the National Earthquake Hazards Reduction Program (NEHRP) (BSSC 2001), the IBC Code (ICC 2006), the Australian Standards Part 4: Earthquake Actions in Australia (Standards Australia 2007), the China Code for Seismic Design of Buildings (China Net for Engineering Construction Standardization 2010), and the Indian Standard Criteria for Earthquake Resistant Design of Structures. Part 1-General Provisions and Buildings [Bureau of Indian Standards (BIS) 2002]. To avoid confusion, only the key information is presented in Table 1 for direct comparison. Soil sites are mainly described based on average SWVs, SPT-N values, and undrained shear strengths $\left(S_{u}\right)$. In this study, site classifications using SPT-N and SWV are considered, as $S_{u}$ is not considered in all the design codes considered herein.

The equivalent shear stiffness values of soil sites based on SPT-N or SWV over 30-m depth $\left(N_{30}\right.$ or $\left.V_{s, 30}\right)$ can be calculated by

$$
N_{30} \text { or } V_{s, 30}=\frac{\sum_{i=1}^{n} d_{i}}{\sum_{i=1}^{n}\left(\frac{d_{i}}{N_{i} \text { or } V_{s i}}\right)}
$$

where $\sum_{i=1}^{n} d_{i}=$ total depth for 30-m average $\sum_{i=1}^{n} d_{i}=30 \mathrm{~m} ; d_{i}$ and $V_{s i} / N_{i}$ denote thickness (in meters) and corresponding shear wave velocity/standard penetration resistance (not to exceed 100 blows $/ 0.3$ $\mathrm{m}$ as directly measured in the field without corrections) of the $i$ th layer, respectively; and $n=$ total number of layers in the top $30 \mathrm{~m}$. Table 1 IBC (ICC 2006) and NEHRP (BSSC 2001). It can be observed that site classification systems in the IBC (ICC 2006) and NEHRP (BSSC 2001) are identical: they consider five different site classes together with one special site class (Site Class F) for very loose soil for which site-specific study is recommended. Standards Australia (2007) recommends five methods to classify a site; site class based on geotechnical details is the preferred method. General site classification according to Standards Australia is based on average SWVs and SPT-N values, as given in Table 1. A detailed site classification procedure recommended under the Chinese code (China Net for Engineering Construction Standardization 2010) is described in Chapter 4, Section 4.1 .6 of the code. It also includes provision for fault and liquefiable soil within the site. Site classifications are based on average SWV of top 20-m soil layers $\left(V_{s, 20}\right)$ (Table 1$)$. There is no separate shows the site classifications based on $V_{s, 30}$ or $N_{30}$ according to the

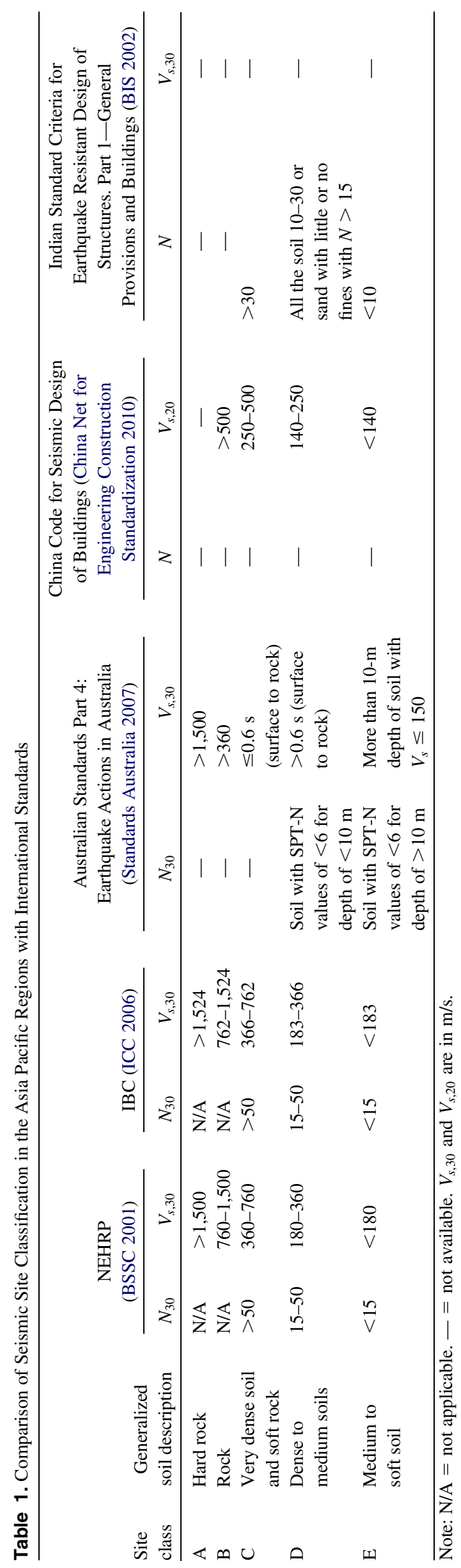

110 / NATURAL HAZARDS REVIEW @ ASCE / MAY 2013 
section for site classification that considers geotechnical characteristics of sites in the Indian code (BIS 2002). However, Section 6.3.5.2 of the code describes general consideration of site conditions by specifying SPT-N values and types of foundation. Site classification in the Indian code (BIS 2002) is based only on SPT-N values, as shown in Table 1.

\section{Site Classification Based on SPT Data}

Boreholes with SPT-N values are one of the oldest and most common tests used in situ for soil exploration in soil mechanics and foundation

Table 2. Summary of Selected Soil Profiles with Standard Penetration Test-N Values

\begin{tabular}{llcll}
\hline $\begin{array}{l}\text { Borehole } \\
\text { number }\end{array}$ & Country & $\begin{array}{c}\text { Depth }(\mathrm{m}) \\
\text { of profile }\end{array}$ & $\begin{array}{c}\text { Weathered and } \\
\text { engineering- } \\
\text { rock depth (m) }\end{array}$ & $\begin{array}{c}\text { General } \\
\text { soil layers } \\
\text { description }\end{array}$ \\
\hline 1 & Australia & 8.2 & 8.2 & Sand, silty sand, \\
2 & Australia & 17 & 17 & silty clay up to rock \\
3 & Australia & 6.2 & 6.2 & Sand, clay, silty clay \\
4 & China & 46.5 & 46.5 & and debris flow \\
& & & & Red soil, sand, \\
5 & India & 6 & 2.5 and 6 & clay and rock \\
6 & India & 10.5 & 6 and 9 & \\
7 & India & 26 & 9 and 12.5 & \\
8 & India & 24.5 & 3.5 and 8 & \\
9 & India & 26 & 6 and 8 & \\
10 & India & 30 & 3 and 6 & \\
11 & India & 16.5 & 17.5 and 22.5 & \\
12 & India & 9 & 16 and 20.5 & \\
13 & India & 12.5 & 12 & \\
14 & India & 8 & 9.5 and 10.5 & \\
15 & India & 8 & 14.5 and 26 & \\
16 & India & 6 & 24.5 & \\
17 & India & 22.5 & 24.5 and 26 & \\
18 & India & 20.5 & 27 and 30 & \\
19 & India & 12 & 16.5 & \\
\hline & & & & \\
\hline
\end{tabular}

engineering. This test has been used worldwide in geotechnical projects, because of simplicity of the equipment and the ease of test procedure. In particular, SPT-N values are widely used for seismic site characterization, site response, and liquefaction studies for detecting seismic microzonation because of the availability of large data sets. However, these SPT-N values may vary even for identical soil conditions because of their high sensitivity to operator techniques, types of equipment, equipment malfunctions, and poor testing practices (Anbazhagan et al. 2012). Hence, SPT-N values are generally recommended only for projects at the preliminary stage or that are under financial constraint (Anbazhagan and Sitharam 2010). In the current study, SPT-N values of the selected soil profiles have been collected from Australia, China, and India (IEA 1990; Pappin et al. 2008; Anbazhagan and Sitharam 2009b; Anbazhagan et al. 2011a). In total, 19 boreholes with SPT-N values have been selected for this study. A summary of these data are given in Table 2.

Equivalent SPT-N values for 30- and 20-m depths have been estimated using Eq. (1) and presented in Fig. 2. SPT-N values have been used to classify the sites according to the IBC (2006) and NEHRP (BSSC 2001). According to the IBC (ICC 2006) and NEHRP (BSSC 2001), all $N_{30}$ values above 50 are grouped in Site Class C. No $N_{30}$ based criterion are given for Site Classes A and B, which may mean $N_{30}$ of 55,70 , and 85 belong to Site Class C. The Chinese code (China Net for Engineering Construction Standardization 2011) recommends measuring SWV for site classification; no site class based on SPT-N value is recommended. However, for building categories $\mathrm{C}$ or $\mathrm{D}$ (and for buildings less than 10 stories and not more than $30 \mathrm{~m}$ in height), estimates of SWV based on known geologic conditions are permitted. The Indian code (BIS 2002) suggests three site classes based on SPT-N values (not average SPT$\mathrm{N}$ values of top 30 -m soil layers). The site classification in the Indian code (BIS 2002) may be considered very simple compared with other contemporary codes, and may not be capable of providing accurate site response parameters.

\section{Site Classification Based on SWV}

The subsurface SWV measurement has been used in many seismic site classification, site response, and microzonation studies. A

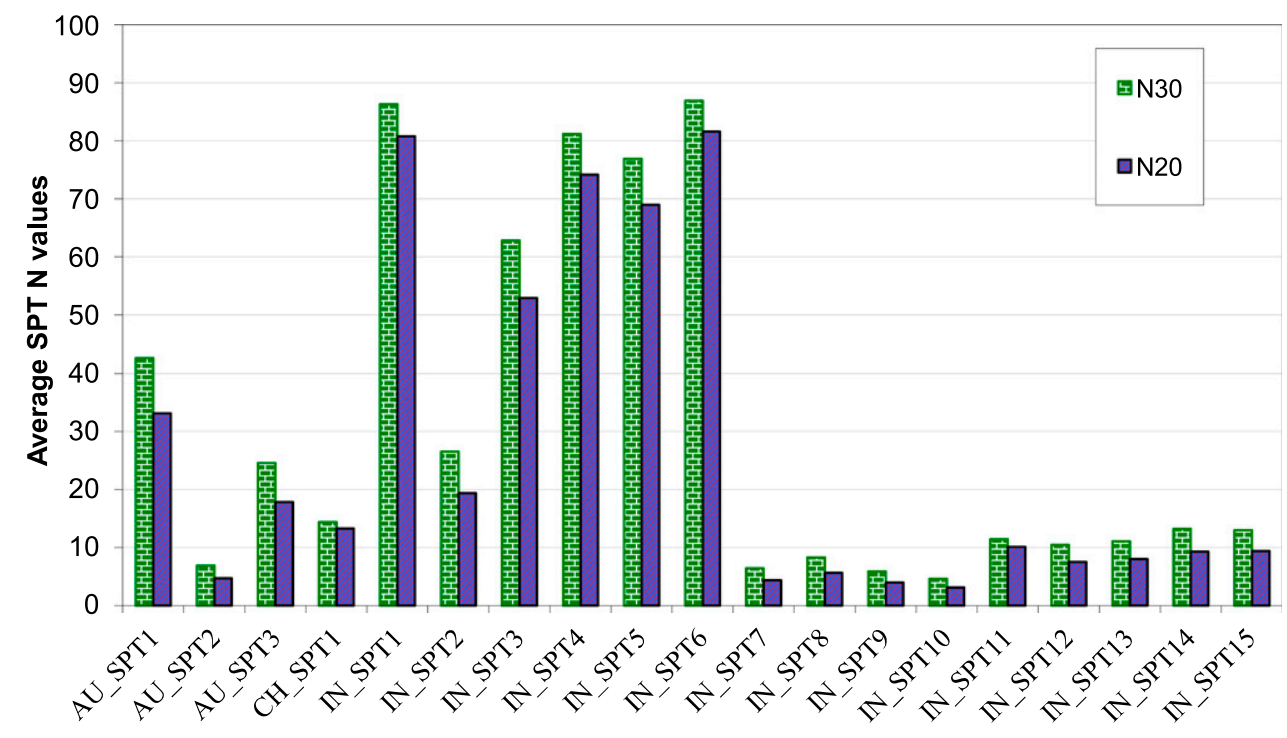

Fig. 2. Average SPT-N values based on the IBC (ICC 2006) and NEHRP (BSSC 2001) and the Chinese code (China Net for Engineering Construction Standardization 2010) [Note: for the IBC (ICC 2006) and NEHRP (BSSC 2001), the average SPT-N value is calculated based on top 30-m soil layers; for the Chinese code (China Net for Engineering Construction Standardization 2010), the calculation is based on top 20-m soil layers] 
Table 3. Summary of Selected Shear Wave Velocity Profiles

\begin{tabular}{|c|c|c|c|c|}
\hline $\begin{array}{l}\text { Shear wave } \\
\text { velocity } \\
\text { profile } \\
\text { number }\end{array}$ & Country & $\begin{array}{l}\text { Depth of } \\
\text { profile }(\mathrm{m})\end{array}$ & $\begin{array}{l}\text { Weathered } \\
\text { rock depth }(\mathrm{m}) \\
(360 \pm \mathrm{m} / \mathrm{s})\end{array}$ & $\begin{array}{c}\text { Engineering } \\
\text { rock depth }(\mathrm{m}) \\
(700 \pm 70 \mathrm{~m} / \mathrm{s})\end{array}$ \\
\hline 1 & Australia & 100 & 2.97 & 3.5 \\
\hline 2 & Australia & 150.62 & 2.6 & 4 \\
\hline 3 & Australia & 180 & 4 & 37 \\
\hline 4 & Australia & 98 & 16 & 42.4 \\
\hline 5 & Australia & 110 & 7 & 22.41 \\
\hline 6 & China & 16.5 & 3.5 & 16.5 \\
\hline 7 & China & 24 & 10.5 & 18.5 \\
\hline 8 & China & 30 & 2 & 19.5 \\
\hline 9 & China & 55 & 2 & 25 \\
\hline 10 & China & 44.5 & 32.5 & 40 \\
\hline 11 & China & 60 & 18 & 60 \\
\hline 12 & China & 96 & 19.5 & 59 \\
\hline 13 & China & 60 & 44.5 & 55.5 \\
\hline 14 & China & 60 & 29 & 43.98 \\
\hline 15 & India & 140 & 1 & 122 \\
\hline 16 & India & 10 & 4.67 & 10 \\
\hline 17 & India & 72 & 13.6 & 57 \\
\hline 18 & India & 69 & 17.54 & 68.96 \\
\hline 19 & India & 27 & 16.88 & - \\
\hline 20 & India & 41 & 19.25 & - \\
\hline 21 & India & 28 & 27.93 & - \\
\hline 22 & India & 64 & 6.2 & 16.4 \\
\hline 23 & India & 69 & 6.5 & 12.3 \\
\hline 24 & India & 63 & 6.7 & 15.9 \\
\hline 25 & India & 22 & - & - \\
\hline 26 & India & 28 & 5.04 & 17.29 \\
\hline 27 & India & 26 & 16.15 & - \\
\hline 28 & India & 60 & 11.5 & 13.5 \\
\hline 29 & India & 16.5 & 15 & - \\
\hline 30 & India & 27.5 & 4.9 & 12.85 \\
\hline 31 & India & 44.4 & 5.25 & 20.76 \\
\hline
\end{tabular}

Note: $-=$ not available. Profiles highlighted in bold are used for site response study (details are given in Table 5). number of seismic methods have been proposed for near-surface characterization and measurement of SWVs using a number of testing configurations, processing techniques, and inversion algorithms. The most widely used techniques are the spectral analysis of surface waves (SASW) and the multichannel analysis of surface waves (MASW). In SASW, the spectral analysis is performed for a surface wave generated by an impulsive source and recorded by a pair of receivers. MASW is increasingly being applied in earthquake geotechnical engineering for seismic microzonation and site response studies (Anbazhagan and Sitharam 2008a,b; Sitharam and Anbazhagan 2008; Anbazhagan et al. 2009, 2010). SWVs of soil layers of the Indian sites have been measured by P. Anbazhagan (this paper) using an MASW survey. More details about the survey, geophone spacing, short distance, and dispersion and inversion processes are described in Anbazhagan and Sitharam (2008a, b; $2009 a, b)$. A few shear wave velocity profiles have also been collected from Boominathan (2004), Boominathan et al. (2008), and Uma Maheswari et al. (2008). SWV profiles of Australia sites have been compiled from Collins et al. (2006). Similarly, SWV profiles of China sites have been collected from Song et al. (2007) and Hwang et al. (2004). Selected soil sites with shear wave velocity profiles have been summarized in Table 3 .

Average SWVs up to depths of $30 \mathrm{~m}$ and $20 \mathrm{~m}$ have been calculated using Eq. (1) and are presented in Fig. 3. For sites having SWVs of less than 30-m depth, extrapolations have been carried out according to Boore (2004). In Fig. 3, 76\% of sites are classified as Site Class D, and 5\% are Site Class E. Australian Sites 1 and 2 are classified as Site Classes A and B, respectively, according to the IBC (ICC 2006) and NEHRP (BSSC 2001). Site classification definition in the Standards Australia (2007) is similar to the IBC (ICC 2006) and NEHRP (BSSC 2001) recommendation for Site Class A. However, for Site Class B, Standards Australia (2007) recommends SWVs of greater than $360 \mathrm{~m} / \mathrm{s}$, which corresponds to Site Class C in the IBC (ICC 2006) and NEHRP (BSSC 2001). Standards Australia (2007) recommends low-amplitude natural site period as criteria for Site Classes C and D, which is different from the recommendation of the IBC (ICC 2006) and NEHRP (BSSC 2001). Standards Australia (2007) recommends SWVs less than $150 \mathrm{~m} / \mathrm{s}$ for Site Class E, which is lower than the IBC (ICC 2006) and NEHRP (BSSC

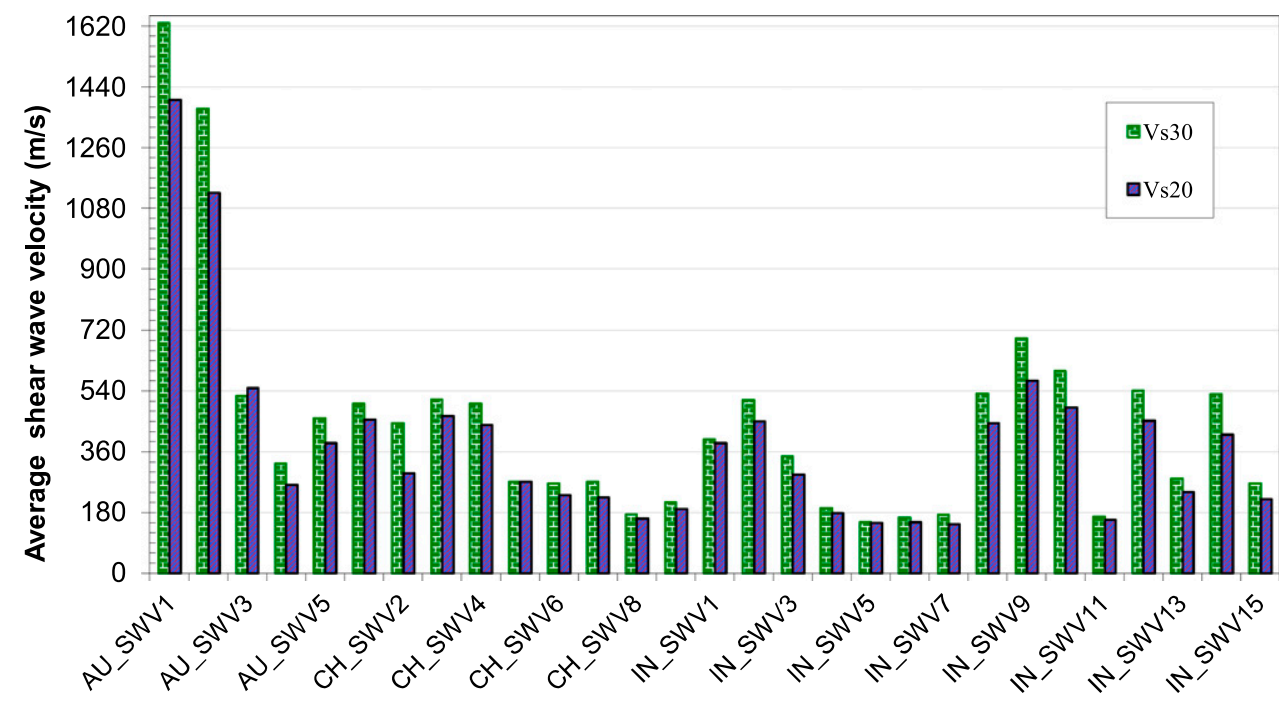

Fig. 3. Average shear wave velocities (SWVs) based on the IBC (ICC 2006) and NEHRP (BSSC 2001) and the Chinese code (China Net for Engineering Construction Standardization 2010) [Note: for the IBC (ICC 2006) and NEHRP (BSSC 2001), the average SWV is calculated based on top 30-m soil layers; for the Chinese code (China Net for Engineering Construction Standardization 2010), the calculation is based on top 20-m soil layers] 
2001) recommendation. The Chinese code (China Net for Engineering Construction Standardization 2010) classifies sites into four classes based on average SWV of top 20-m soil layers. The range of values specified in Table 4.1.6 of the Chinese code (China Net for Engineering Construction Standardization 2010) is much lower than those in the IBC (ICC 2006) and NEHRP (BSSC 2001). The Indian code (BIS 2002) classifies sites into three site classes based on measured $n$-values. No SWV values have been recommended in the Indian code (BIS 2002). It is apparent that site classes according to the Indian code are not well defined and hence may not provide similar site response parameters compared with other codes.

\section{Proposal for Alternative Site Classification Scheme}

Site amplification ratios for different site classes (based on average SWV of top 30-m soil layers) recommended in the IBC (ICC 2006) and NEHRP (BSSC 2001) is based on regression analysis of strong motion records at different soil sites. It is noted that the IBC (ICC 2006) and NEHRP (BSSC 2001) allows for site-specific ground response studies when the generalized site classification and site amplification ratios are judged to be inadequate for any specific site (for example, shallow soil sites over hard bedrock giving rise to high impedance contrast). Site amplification ratios developed in the IBC (ICC 2006) and NEHRP (BSSC 2001), therefore, cannot be applied for shallow bedrock regions. Hence, development of a site classification scheme for shallow bedrock regions is important.

\section{Site Classification Considering Weathered Rock Layer}

Average SPT-N and shear wave velocity measurements up to weathered rock layers (soil depths may be different from $30 \mathrm{~m}$ ) have been calculated to classify the sites using Eq. (1) and following the recommendation of the IBC (ICC 2006) and NEHRP (BSSC 2001) to classify the soil. Weathered rock depth can be identified from borelog data rather than SPT-N values. In most cases, SPT-N values more than 50 represent dense layers or weathered rock layers. After studying borelog data carefully, weathered rock depths have been identified for the selected soil sites. Average SPT-N values up to weathered rock depth $\left(N_{\mathrm{WR}}\right)$ have been calculated and shown in Fig. 4(a). It can be observed from Fig. 4(a) that $N_{30}$ and $N_{20}$ (average SPT-N values up to $30-\mathrm{m}$ and $20-\mathrm{m}$ soil layers, respectively) are higher than $N_{\mathrm{WR}}$, implying that $N_{30}$ and $N_{20}$ provides stiffer site classes compared with $N_{\mathrm{WR}}$. When weathered rock depth is within $10 \mathrm{~m}$, the site-class variation is considerable. The SWV of weathered rock has been estimated as $330 \pm 30 \mathrm{~m} / \mathrm{s}$. Average shear wave velocity up to weathered rock $\left(V_{s, \mathrm{WR}}\right)$ has been estimated and is shown in Fig. 4(b). In Fig. 4(b), it is shown that if weathered rock depth is within $15 \mathrm{~m}, V_{s, \mathrm{WR}}$ is much less than $V_{s, 30}$ or $V_{s, 20}$ (average shear wave velocity up to $30 \mathrm{~m}$ and $20 \mathrm{~m}$ soil layers, respectively). Site classification based on $V_{s, 30}$ and $V_{s, 20}$ may represent stiffer site classes and in turn may underestimate response spectral ordinates. Such underestimation may have significant consequences in designing civil infrastructure. This issue has been further investigated later in the article under Site Response Parameters for Soil Sites with Shallow Depth of Engineering Bedrock.

\section{Site Classification Considering Engineering-Rock Layer}

Although weathered rock is stiffer than overlaying soil layers, in many cases it is not straightforward to differentiate between dense soil and weathered rock layers based only on SPT-N and SWVs, unless a detailed borelog study is available. Hence, site classifications considering soil layers up to weathered rock may be subjected to
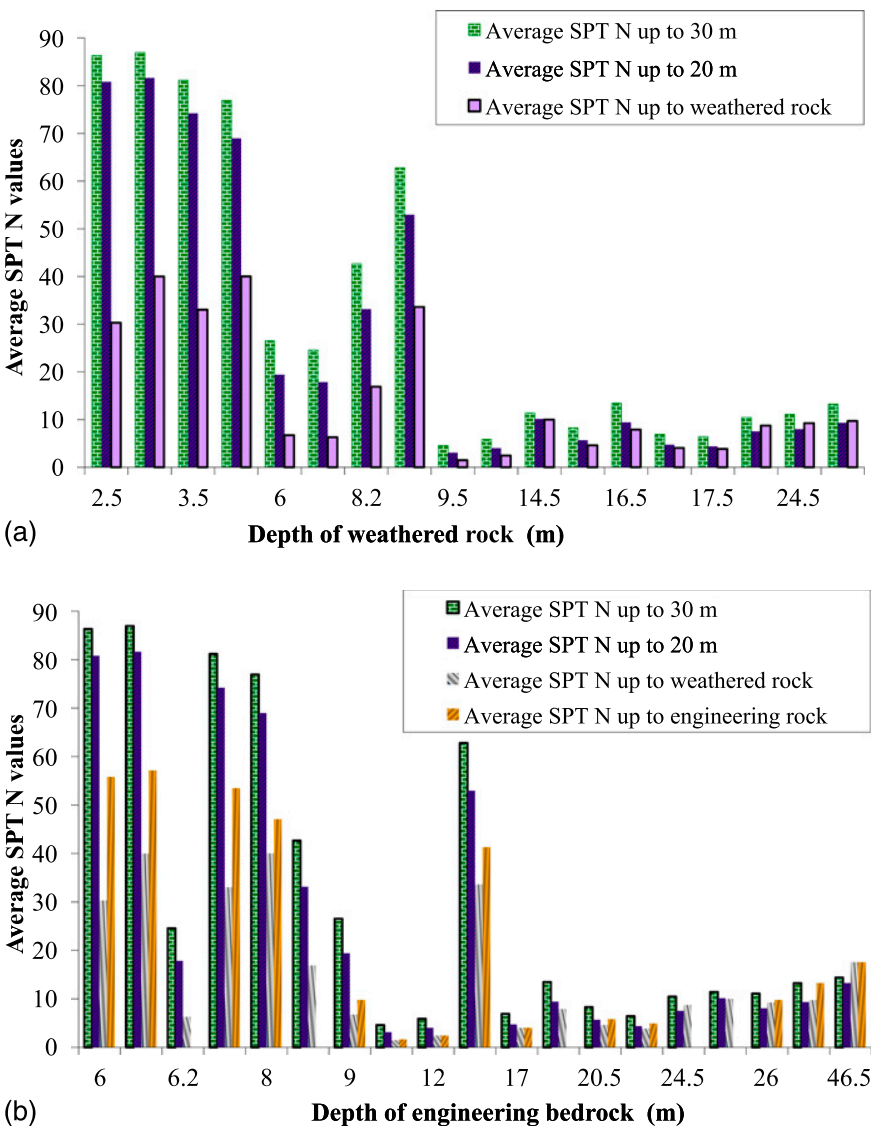

Fig. 4. (a) Comparison of average SPT-N values calculated based on the depth of weathered rock layers with average SPT-N values calculated based on the IBC (ICC 2006) and NEHRP (BSSC 2001) (based on top 30-m soil layers) and the Chinese code (China Net for Engineering Construction Standardization 2010) recommendations (based on top 20$\mathrm{m}$ soil layers); (b) comparison of average SWVs calculated based on the depth of weathered rock layers with average SWVs calculated based on the IBC (ICC 2006) and NEHRP (BSSC 2001) (based on top 30-m soil layers) and the Chinese code (China Net for Engineering Construction Standardization 2010) recommendations (based on top 20-m soil layers)

significant criticism. In this study, site classifications considering average SPT-N values and SWVs up to engineering bedrock have been attempted. Substructures of most of the important engineering structures are extended up to the rock where there are SPT-N values of 100 for no penetrations or SWVs of $760 \mathrm{~m} / \mathrm{s}$ (Anbazhagan and Sitharam 2009b). This rock layer can be called engineering bedrock (Anbazhagan and Sitharam 2009b). The engineering bedrock layer has been identified from borelogs of SPT-N data, considering a layer corresponding to SWV of $760 \times 60 \mathrm{~m} / \mathrm{s}$. Average SPT-N and SWV values have been calculated up to an engineering bedrock layer. In Fig. 5(a), the average SPT-N values up to engineering bedrock $\left(N_{\mathrm{ER}}\right)$ versus depth of engineering bedrock along with $N_{\mathrm{WR}}, N_{30}$, and $N_{20}$ are shown. The $N_{30}$ and $N_{20}$ calculate higher average SPT-N values for sites having engineering-rock layers at shallow depths compared with $N_{\mathrm{ER}}$ and $N_{\mathrm{WR}}$. The $N_{\mathrm{WR}}$ is slightly lower than $N_{\mathrm{ER}}$ for an engineering bedrock depth up to 20 $\mathrm{m}$, and beyond this range they are quite similar. In Fig. 5(b), $V_{s, \mathrm{ER}}$ versus depth of engineering bedrock for selected soil profiles along with $V_{s, \mathrm{WR}}, V_{s, 30}$, and $V_{s, 20}$ is shown. Average SWV up to engineering bedrock $\left(V_{s, \mathrm{ER}}\right)$ is less than $V_{s, 30}$ if engineering-rock depth is less than $25 \mathrm{~m}$, and more than $V_{s, 30}$ if engineering-rock depth is 

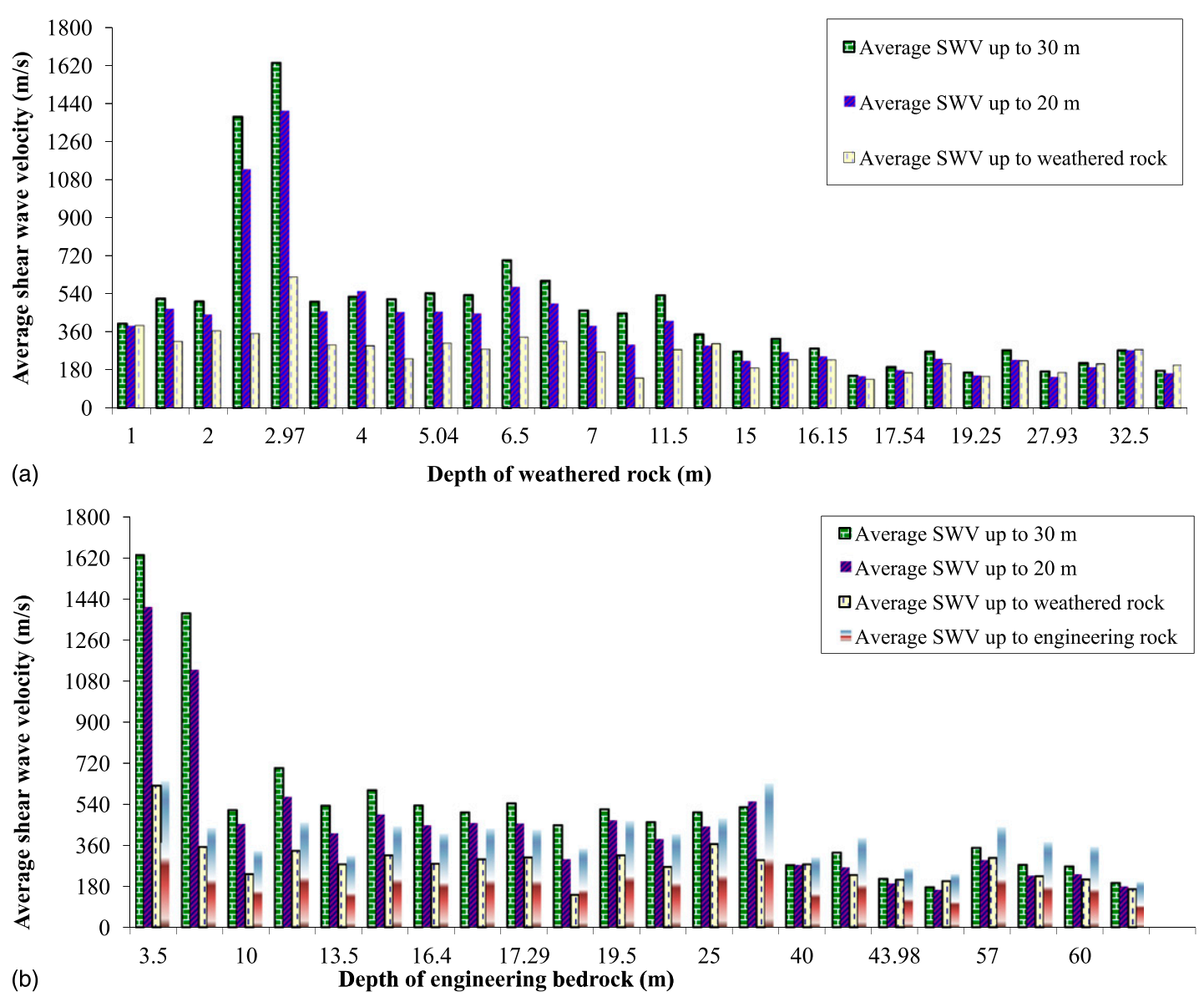

Fig. 5. (a) Comparison among average SPT-N values calculated based on the depth of engineering-rock layers, weathered rock layers, the IBC (ICC 2006) and NEHRP (BSSC 2001) recommendations (based on top 30-m soil layers), and the Chinese code (China Net for Engineering Construction Standardization 2010) recommendations (based on top 20-m soil layers); (b) comparison among average SWVs calculated based on the depth of engineering-rock layers, weathered rock layers, the IBC (ICC 2006) and NEHRP (BSSC 2001) recommendations (based on top 30-m soil layers) and the Chinese code (China Net for Engineering Construction Standardization 2010) recommendations (based on top 20-m soil layers)

more than $35 \mathrm{~m}$. It is noted that $V_{s, \mathrm{ER}}$ values are equal to $V_{s, 30}$ and $V_{s, 20}$ when the engineering-rock depth is $30 \mathrm{~m}$ and $20 \mathrm{~m}$, respectively. Average shear wave velocity up to engineering bedrock can be considered more representative for site effect calculations, especially for soil sites in regions of low to moderate seismicity. This study shows that rock depth plays an important role in the site classifications. Site classification-based average values up to $30 \mathrm{~m}$ give a stiffer site class if engineering bedrock is less than $25 \mathrm{~m}$. This has been further verified using site-specific response analysis that considers a typical SWV profile with simulated and recorded ground motion data, and is reported in the following section.

\section{Site Response Parameters for Soil Sites with Shallow Depth of Engineering Bedrock}

As discussed earlier, site amplification factors derived from regression analyses of recorded strong motion data from deep soil sites cannot be applied to shallow bedrock regions. The IBC (2006) and NEHRP (BSSC 2001) site classifications are developed from regression analyses of sites having no distinct soil-bedrock interface even at a depth significantly greater than $100 \mathrm{~m}$. Both the IBC (ICC 2006) and NEHRP (BSSC 2001) recommend site-specific studies for situations where generalized site classifications do not fit. For regions lacking a large amount of recorded strong motion data, it is usual to carry out site response studies using the well-known computer program SHAKE (Schnabel et al. 1972). SHAKE is a one-dimensional site response analysis software that adopts an equivalent linear approach to calculating the nonlinear behavior of the soil sites subjected to earthquake ground motion. SHAKE is a robust seismic site response analysis program which provides reasonable approximation to the site response simulations with a minimal input. Borcherdt (1994) and Crouse and McGuire (1996) applied SHAKE in supplementing their analyses, which can further ascertain the program's validity in performing site response analyses. In this study, the shear modulus degradation and damping curves given by Seed and Idriss (1970) and Schnabel (1973) for sand average and rock have been used for soil and rock layers, respectively.

\section{Earthquake Ground Motion Records for Site Response Study}

A large number of damaging earthquakes with varying magnitudes have occurred in low to moderate seismicity regions including India and China. However, only a limited number of recorded acceleration time histories, especially for India and China, are available for carrying out site response analyses. For regions having limited or no seismic record, synthetic ground motion or ground motions from similar tectonic regions may be considered a viable alternative (Sitharam and Anbazhagan 2007). Seismological models developed 
by Boore $(1983,2003)$ have been widely used for the generation of synthetic acceleration time histories (Atkinson and Boore 1995; Hwang and Huo 1997). To carry out site response analyses under moderate earthquake ground motions, a synthetic ground motion generated by Sitharam and Anbazhagan (2007) using a seismological modeling approach has been used in this study. In Fig. 6(a), synthetic ground motion, applied as input earthquake ground motion for the site response analysis in this study, is shown. The synthetic ground motion generated has a peak acceleration of $0.155 g$ for a moment magnitude of 5.1 and can be considered as representative of a moderate magnitude intraplate earthquake event. A typical interplate earthquake event recorded at Chamoli, Uttarakhand, India has been taken from the Atlas of Indian Strong Motion Records (Shrikhande 2001). The Chamoli earthquake occurred on March 29, 1999 at north Chamoli in the Lesser Himalayas. This event has moment magnitude of 6.6 and peak ground acceleration of $0.19 g$
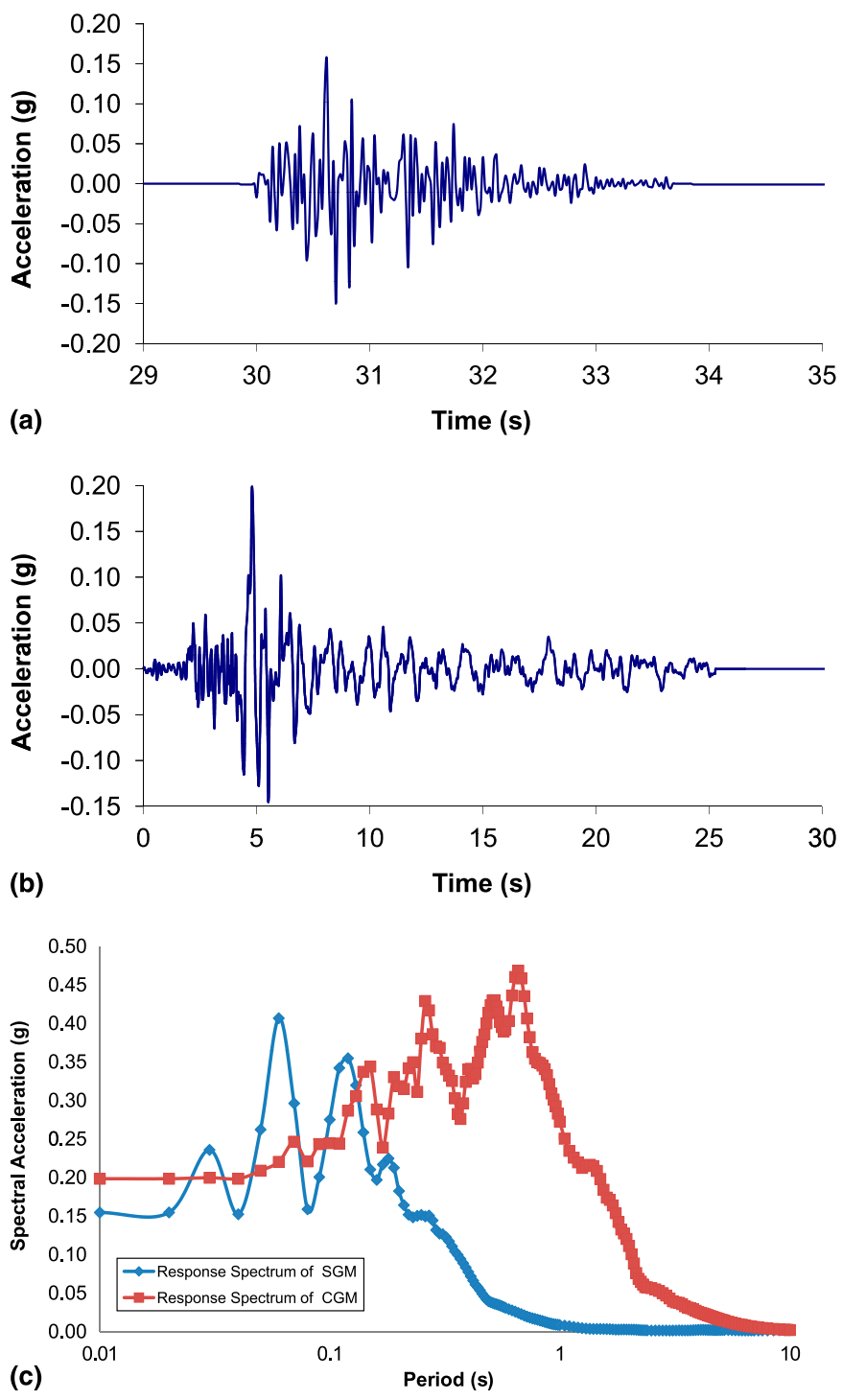

Fig. 6. (a) Ground motion time history applying as input ground motion for site response analysis: synthetic ground motion for $M_{\mathrm{w}}$ (moment magnitude) of 5.1 intraplate earthquake; (b) ground motion time history applying as input ground motion for site response analysis: recorded ground motion at rock site in Chamoli, $M_{\mathrm{w}}$ of 6.6 interplate earthquake; (c) ground motion time history applying as input ground motion for site response analysis: response spectrum of time history of Figs. 6(a and b) recorded at rock level. In Fig. 6(b), the acceleration time history of the Chamoli earthquake is shown. In Fig. 6(c), the response spectrum of time history considered in this study is shown.

\section{Site Response Analysis}

Using the program SHAKE, SPT-N values are converted to shear modulus using simple equations without considering the differences in hammer energy applied in obtaining SPT-N values. Recently Anbazhagan et al. (2012) reviewed the limitations of existing shear modulus versus SPT-N value correlations. Considering the limitation of using SPT-N values in the site response analysis, soil sites with only SPT-N values are not considered for site response analysis in this paper. Typical shear wave velocity profiles reflecting a shallow engineering bedrock are selected from the data set for site response analyses. Site response analyses are first carried out based on hypothetical shear wave velocity profiles representing soft to dense soil having the same thickness above rock layers. These are representative of filled materials above rock (i.e., filling of lakes). Analyses have then been carried out based on measured SWV profiles for loose to dense soils having different engineering-rock depths. It is noted that accelerograms were applied as rock outcrop motion in the site response analyses using SHAKE, and the rock half-space has been considered to be at the top of the bedrock layers considered.

Hypothetical shear wave velocity profiles are referred to here as HSWVPs. In Fig. 7, HSWVPs for loose, medium-dense, dense, and very dense soils, together with engineering-rock layers above hard rock (the description of the sites herein is based on the average SWV up to engineering-rock levels), are shown. These repetitive materials have the thickness of $4 \mathrm{~m}$ and are placed above hard rock that has a shear wave velocity of $1385 \mathrm{~m} / \mathrm{s}$. Summary of the hypothetical soil sites are given in Table 4. HSWVPs 1-4 are classified as Site Class B (rock), based on average SWV up to 30-m soil depth according to the IBC (ICC 2006) and NEHRP (BSSC 2001). Similarly HSWVP5 is

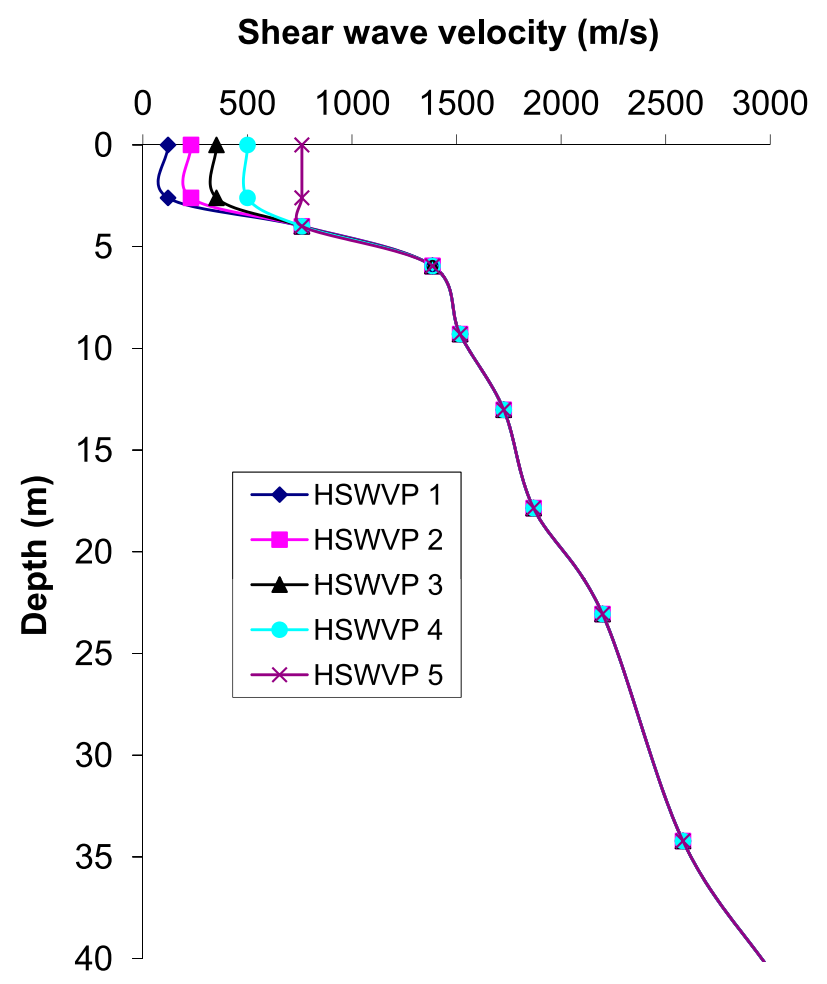

Fig. 7. Hypothetical SWV profiles for different soil types underlain by hard rock layers 
Table 4. Summary of Hypothetical Shear Wave Velocity Profiles Used to Estimate Site Response Parameters

\begin{tabular}{|c|c|c|c|c|c|}
\hline Parameters & $\begin{array}{c}\text { Hypothetical shear } \\
\text { wave velocity } \\
\text { profiles } 1\end{array}$ & $\begin{array}{c}\text { Hypothetical shear } \\
\text { wave velocity } \\
\text { profiles } 2\end{array}$ & $\begin{array}{c}\text { Hypothetical shear } \\
\text { wave velocity } \\
\text { profiles } 3\end{array}$ & $\begin{array}{c}\text { Hypothetical shear } \\
\text { wave velocity } \\
\text { profiles } 4\end{array}$ & $\begin{array}{c}\text { Hypothetical shear } \\
\text { wave velocity } \\
\text { profiles } 5\end{array}$ \\
\hline Soil type & Loose & Medium & Dense & Very dense & Rock \\
\hline Layer thickness-minimum (m) & 1.4 & 1.4 & 1.4 & 1.4 & 4 \\
\hline Layer thickness-maximum (m) & 2.6 & 2.6 & 2.6 & 2.6 & 4 \\
\hline Depth of weathered rock (m) & 4 & 4 & 2.6 & 2.6 & 0 \\
\hline Depth of engineering rock (m) & 4 & 4 & 4 & 4 & 0 \\
\hline Lowest SWV $(\mathrm{m} / \mathrm{s})$ & 120 & 230 & 350 & 500 & 760 \\
\hline$V_{s, 30}$ & 812.449 & $1,129.39$ & $1,324.36$ & $1,466.367$ & $1,606.015$ \\
\hline$V_{s, 20}$ & 608.91 & 889.54 & $1,076.84$ & $1,221.06$ & $1,369.84$ \\
\hline$V_{s, \mathrm{WR}}$ & 120.00 & 230.00 & 351.65 & 500.00 & 760.00 \\
\hline$V_{s, \mathrm{ER}}$ & 170.15 & 304.26 & 433.09 & 568.01 & 760.00 \\
\hline Site class based on $V_{s, 30}$ & B & B & B & B & A \\
\hline Site class based on $V_{s, 20}$ & B & B & B & $\mathrm{B}$ & B \\
\hline Site class based on $V_{s, \text { WR }}$ & $\mathrm{E}$ & $\mathrm{D}$ & $\mathrm{D}$ & $\mathrm{D}$ & $\mathrm{D}$ \\
\hline Site class based on $V_{s, \text { ER }}$ & $\mathrm{E}$ & $\mathrm{D}$ & $\mathrm{D}$ & $\mathrm{D}$ & $\mathrm{D}$ \\
\hline
\end{tabular}

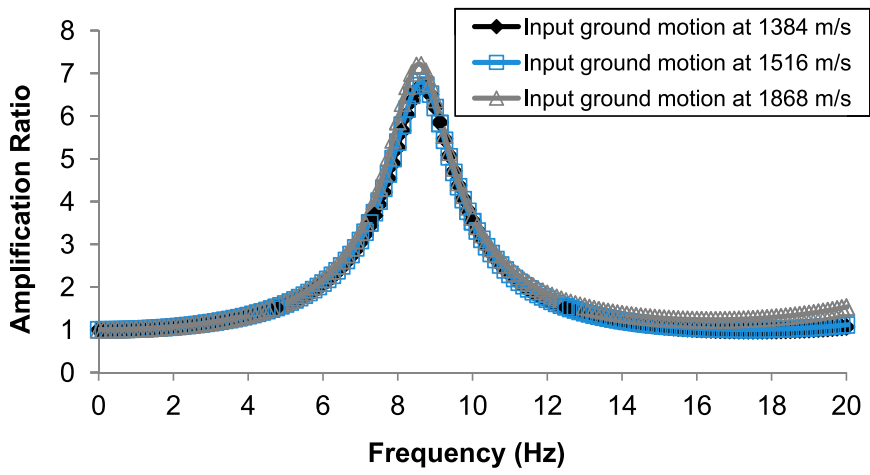

Fig. 8. Amplification ratio of a soil profile applying input earthquake ground motion time history at different rock layers

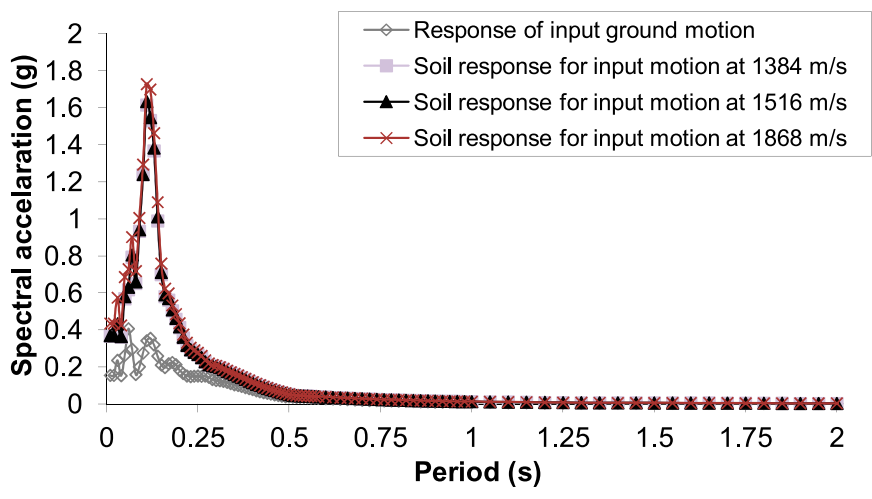

Fig. 9. Response spectra at the surface of a soil site for input ground motion time history at different rock layers

classified as Site Class A (hard rock). These sites are also classified as similar site classes according to Standards Australia (2007) classification (Table 1). However, the sites are classified as Site Class $\mathrm{B}$ according to the Chinese code (China Net for Engineering Construction Standardization 2010) based on average SWV up to 20-m soil depths (Table 1). It is interesting to note that HSWVP1 can be classified as Site Class E and HSWVPs2-5 can be classified as Site Class D, if average SWVs are considered up to engineering rock,
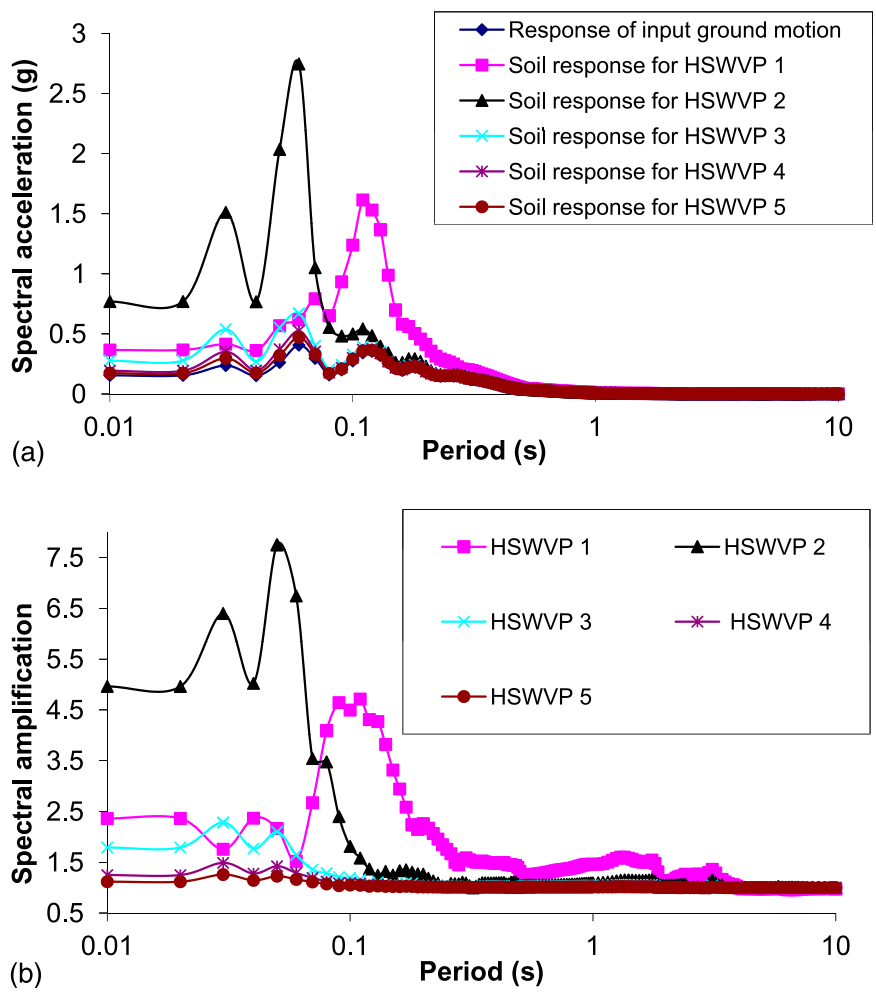

Fig. 10. (a) Response spectra at soil surface for hypothetical soil columns having same soil thickness but different soil stiffness when synthetic ground motion acceleration time history is applied as input motion at engineering-rock level; (b) response spectral amplification at soil surface for hypothetical soil columns having same soil thickness but different soil stiffness when synthetic ground motion acceleration time history is applied as input motion at engineering-rock level

and the sites are classified based on average SWVs according to the IBC (ICC 2006) and NEHRP (BSSC 2001).

Site response analyses have been carried out using recorded and synthetic earthquake records (discussed earlier) for three bedrock rigidity conditions in the software SHAKE2000 (Ordonez 2011). This is to investigate whether higher bedrock rigidity can cause significant differences in site response spectra or response spectral 
amplification factors. Input motions are applied at depths where the shear wave velocities of rock materials are $1385 \mathrm{~m} / \mathrm{s}$ (just below engineering bedrock), $1516 \mathrm{~m} / \mathrm{s}$, and $1868 \mathrm{~m} / \mathrm{s}$ for a profile HSWVP1. Input below this layer, i.e., above SWV of greater than $2000 \mathrm{~m} / \mathrm{s}$, has not been permitted by SHAKE2000 (Ordonez 2011), which may be the result of a limitation on stress stain behavior of inbuilt materials. It can be observed from Figs. 8 and 9 that application of input ground motion at different depths within the rock layers does not cause significant differences in amplification ratios or spectral ordinates. Typical amplification ratio versus frequency for input at different rock levels is shown in Fig. 8. In Fig. 9, response spectra of soil sites for input motion at different rock levels possessing different SWVs is shown. Hence, it can be concluded, based on the analyses carried out herein, that site response analyses can be carried out with sufficient accuracy by applying input seismic ground motion at or below the engineering-rock level.

Response spectra from the software SHAKE 2000 (Ordonez 2011) for different soil stiffness (HSWVPs 1-5) having the same thickness up to engineering-rock level are shown in Fig. 10(a). In Fig. 10(b), the spectral amplifications are given. Synthetic ground motion corresponding to a moderate earthquake is applied as the input ground motion at engineering-rock level. It can be observed that response spectral ordinates for a medium-dense soil column (HSWVP2) are higher than other soil columns up to period of $0.10 \mathrm{~s}$. However, for a loose soil column (HSWVP1), spectral ordinates are higher for periods from 0.25 to $4.0 \mathrm{~s}$. Spectral values are the same, irrespective of soil column stiffness beyond the period of $4 \mathrm{~s}$. For dense to very dense soil columns (HSWVPs 3-5), spectral values are slightly higher than the response spectrum of input ground motion at rock up to a period of $0.25 \mathrm{~s}$, beyond which soil spectral values are almost similar to values at rock level, as expected for stiffer sites. In Figs. 11(a and b), response spectral acceleration response spectra and response spectral amplifications of HSWVPs are shown for recorded ground motion of the Chamoli earthquake. It can be observed that spectral acceleration and spectral amplification for SWVP1 are higher than those of other soil columns for periods up to $4.0 \mathrm{~s}$. Moreover, spectral amplification is higher than $1.0 \mathrm{~s}$ for SWVP2 for periods up to $1.0 \mathrm{~s}$ (Figs. 11a, b). These sites have been classified as Site Class B (rock) and Site Class A (hard rock) according to the IBC (ICC 2006) and NEHRP (BSSC 2001) (Table 4), as mentioned earlier. It is important to note that for Site Class B, the IBC (ICC 2006) specifies site coefficients (both for short and long periods) as 1 , which means no site amplification factor needs to be adopted. The observation from Figs. 10 and 11 clearly indicates that a site amplification factor must be applied to the response spectrum of input ground motion to achieve realistic response spectra at soil sites. Hence, adopting the site classification scheme according to the IBC (ICC 2006) and NEHRP (BSSC 2001) would underestimate the site response spectrum.

For the next phase of the analyses, the measured shear wave velocity profiles of three soil columns having different depths up to engineering rock are selected, as shown in Fig. 12. The first soil column (SWVP1) represents medium-dense sand. The thickness of the soil profile up to engineering rock is $40 \mathrm{~m}$. Soil layer thickness is approximately $2.5 \mathrm{~m}$. Based on the average SWV of top 30-m soil layers, the site is classified as Site Class D soil. As the depth of the soil layer is more than $30 \mathrm{~m}$, based on average SWV up to engineering rock, the site is classified as Site Class D soil. The second soil column (SWVP2) is a loose to medium dense soil. The depth of engineering bedrock is only $10 \mathrm{~m}$. The thickness of soil layers varies from $0.3 \mathrm{~m}$ to $2 \mathrm{~m}$. Based on average SWV of top 30-m soil layers, this class is classified as Site Class $C$ soil. Whereas, based on average SWV up to engineering rock, the site is also classified as Site Class D soil. The third soil column (SWVP3) represents very dense sand. The depth of the soil column up to engineering bedrock is about $13 \mathrm{~m}$. The thickness of the soil layers varies from $0.85 \mathrm{~m}$ to $2.6 \mathrm{~m}$. Based on
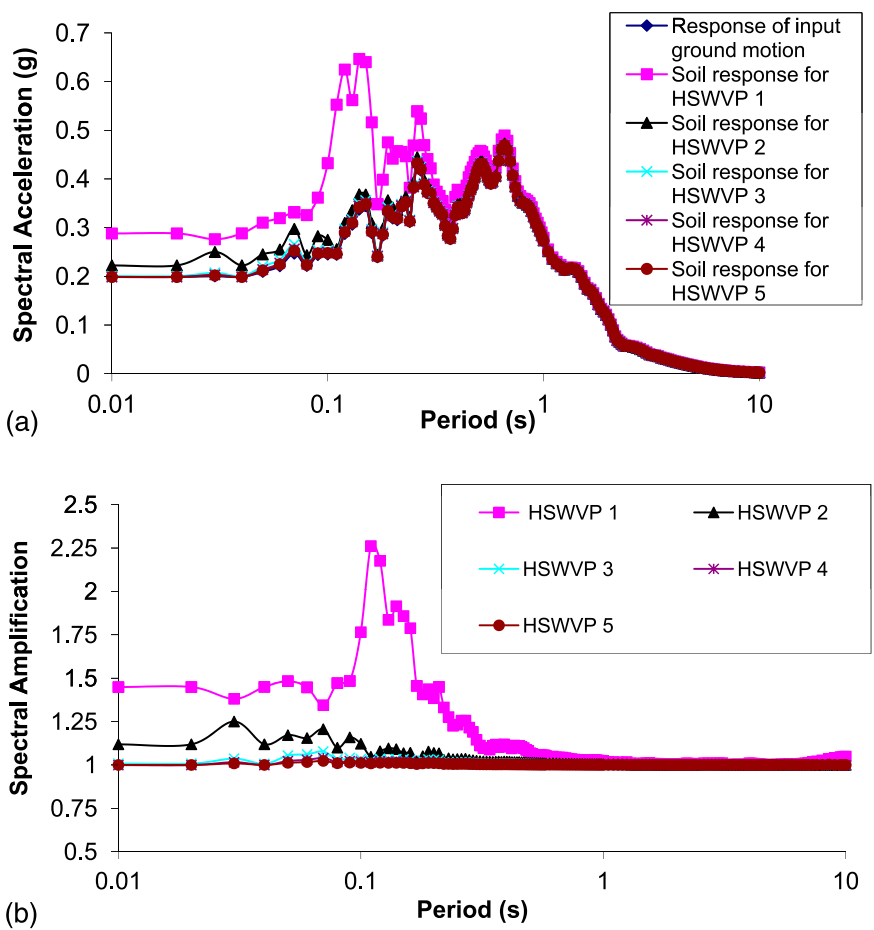

Fig. 11. (a) Response spectra at soil surface for hypothetical soil columns having same soil thickness but different soil stiffness when recorded earthquake ground motion acceleration time history at Chamoli is applied as input motion at engineering-rock level; (b) response spectral amplification at soil surface for hypothetical soil columns having same soil thickness but different soil stiffness when recorded earthquake ground motion acceleration time history at Chamoli is applied as input motion at engineering-rock level

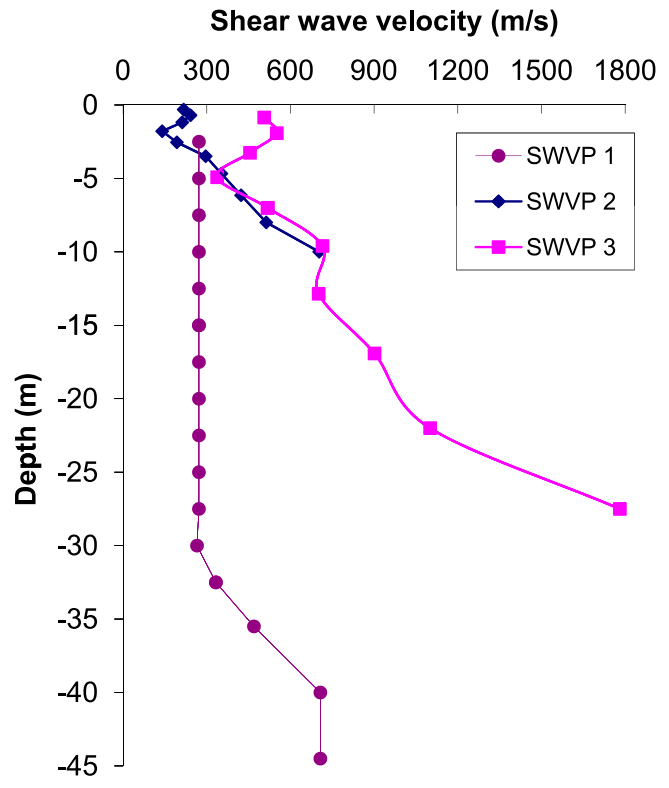

Fig. 12. Measured soil shear wave velocity profiles (SWVPs) with different rock depths used for site response analysis 
the average SWV of top 30-m soil layers, the site is classified as Site Class B soil. However, based on average SWV up to engineering bedrock, the site is classified as Site Class $\mathrm{C}$ soil. The apparent differences in site class for SWVP2 and SWVP3 are from inclusion of rock layers into the top 30-m soil layers, which increased the

Table 5. Summary of Measured Shear Wave Velocity Profiles Used to Estimate Site Response Parameters

\begin{tabular}{lccc}
\hline & $\begin{array}{c}\text { Shear wave } \\
\text { velocity } \\
\text { profile } \\
1(10)\end{array}$ & $\begin{array}{c}\text { Shear wave } \\
\text { velocity } \\
\text { profile } \\
2(16)\end{array}$ & $\begin{array}{c}\text { Shear wave } \\
\text { velocity } \\
\text { profile }\end{array}$ \\
Parameters & Medium & $\begin{array}{c}\text { Loose to } \\
\text { medium }\end{array}$ & $\begin{array}{c}\text { Dense to } \\
\text { very dense }\end{array}$ \\
\hline Soil type & & 0.3 & 0.85 \\
Layer thickness-minimum (m) & 2.5 & 2 & 2.6 \\
Layer thickness-maximum (m) & 2.5 & 4.7 & 4.9 \\
Depth of weathered rock (m) & 32.5 & 10 & 13 \\
Depth of engineering rock (m) & 40 & 140 & 337 \\
Lowest SWV (m/s) & 272 & 513 & 802 \\
$V_{s, 30}$ & 271 & 452 & 643 \\
$V_{s, 20}$ & 272 & 232 & 428 \\
$V_{s, \text { WR }}$ & 275 & 333 & 540 \\
$V_{s, \text { ER }}$ & 306 & $\mathrm{C}$ & $\mathrm{B}$ \\
Site class based on $V_{s, 30}$ & $\mathrm{D}$ & $\mathrm{C}$ & $\mathrm{B}$ \\
Site class based on $V_{s, 20}$ & $\mathrm{C}$ & $\mathrm{D}$ & $\mathrm{C}$ \\
Site class based on $V_{s, \text { WR }}$ & $\mathrm{D}$ & $\mathrm{D}$ & $\mathrm{C}$ \\
Site class based on $V_{s, \mathrm{ER}}$ & $\mathrm{D}$ & $\mathrm{D}$ &
\end{tabular}

Note: Values in parentheses refer to the SWV profile number in Column 1 of Table 3.
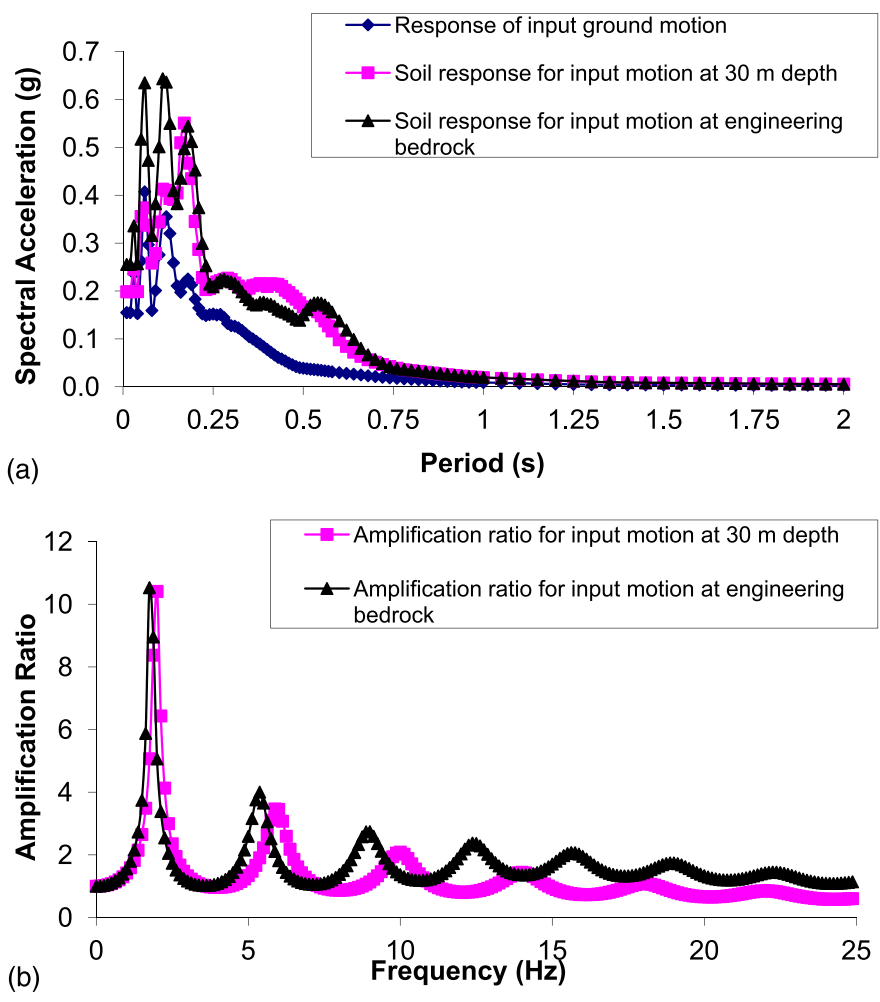

Fig. 13. (a) Response spectrum for SWVP1 when synthetic ground motion is considered as input motion at 30-m depth and at engineeringrock level; (b) amplification ratio for SWVP1 when synthetic ground motion is considered as input motion at 30-m depth and at engineeringrock level average SWV up to depths of soil columns considered. More details of the soil columns have been reported in Table 5.

Response spectra and amplification ratios for SWVPs1-3 under simulated earthquake ground motion and recorded earthquake ground motion at Chamoli have been shown in Figs. 13-18. It can be observed from Fig. 13 that peak response spectral acceleration [Fig. 13(a)] and amplification ratio [Fig. 13(b)] for SWVP1 under simulated earthquake ground motion are the same when the input earthquake ground motion acceleration is applied at 30-m depth and at rock level. It is noted that both $V_{s, 30}$ and $V_{s, \mathrm{ER}}$ approaches represent the soil as Site Class D. It is interesting to note that the frequencies at peak amplification are also the same. The same observation has also been obtained when site response analysis is carried out for recorded earthquake ground motion at Chamoli [Figs. 16(a and b)]. The spectral acceleration and amplification ratio for SWVP2 under simulated earthquake records has been shown in Figs. 14(a and b). Significant differences between peak spectral acceleration [Fig. 14(a)] and peak amplification ratio [Fig. 14(b)] have been observed when input earthquake ground motion is applied at 30-m depth and at engineering-rock levels. Peak response spectral acceleration is higher when input ground motion is applied at $30 \mathrm{~m}$; however, the peak amplification ratio is greater when input earthquake ground motion is applied at engineering-rock level. It is also noted that frequencies corresponding to peak amplifications are different. According to the IBC (ICC 2006) and NEHRP (BSSC 2001) recommendations, this soil profile is classified as a Site Class $\mathrm{C}$ site. It is noted that average response spectral amplification for this soil profile has been observed to be higher than the site coefficient proposed in the IBC (ICC 2006). Based on average SWV up to engineering rock, the soil profile is classified as Site Class D, which seems reasonable
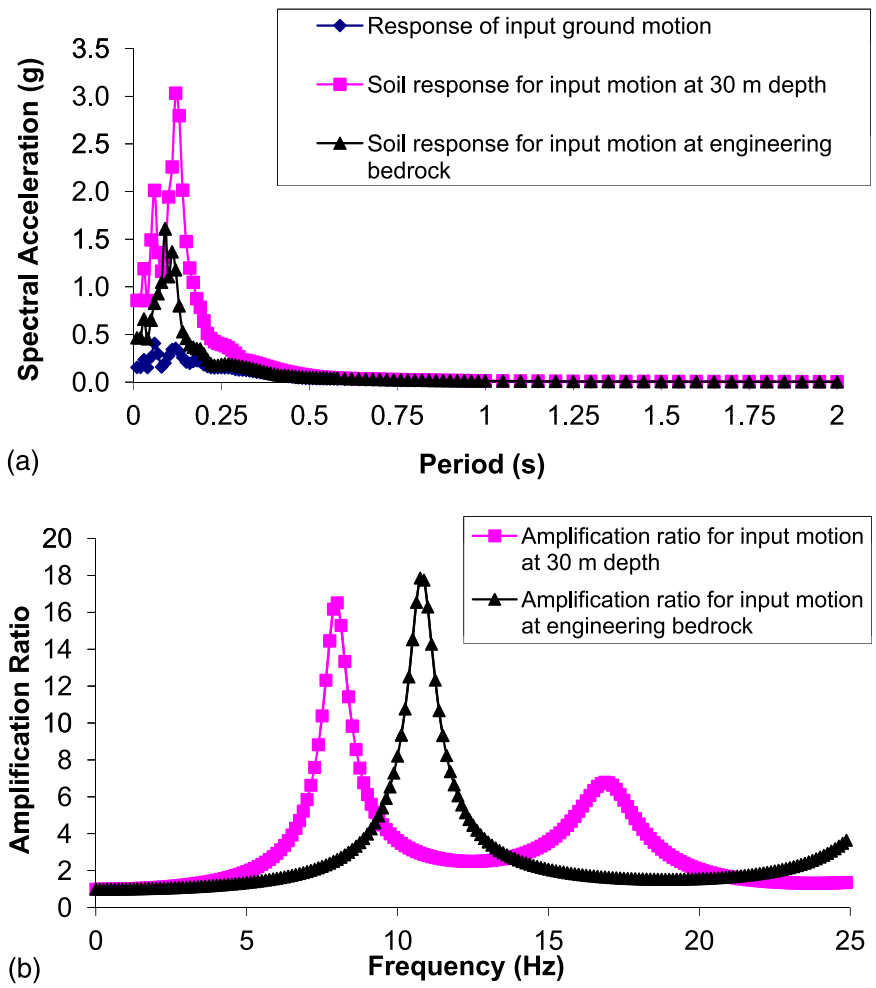

Fig. 14. (a) Response spectrum for SWVP2 when synthetic ground motion is considered as input motion at 30-m depth and at engineeringrock level; (b) amplification ratio for SWVP2 when synthetic ground motion is considered as input motion at 30-m depth and at engineeringrock level 

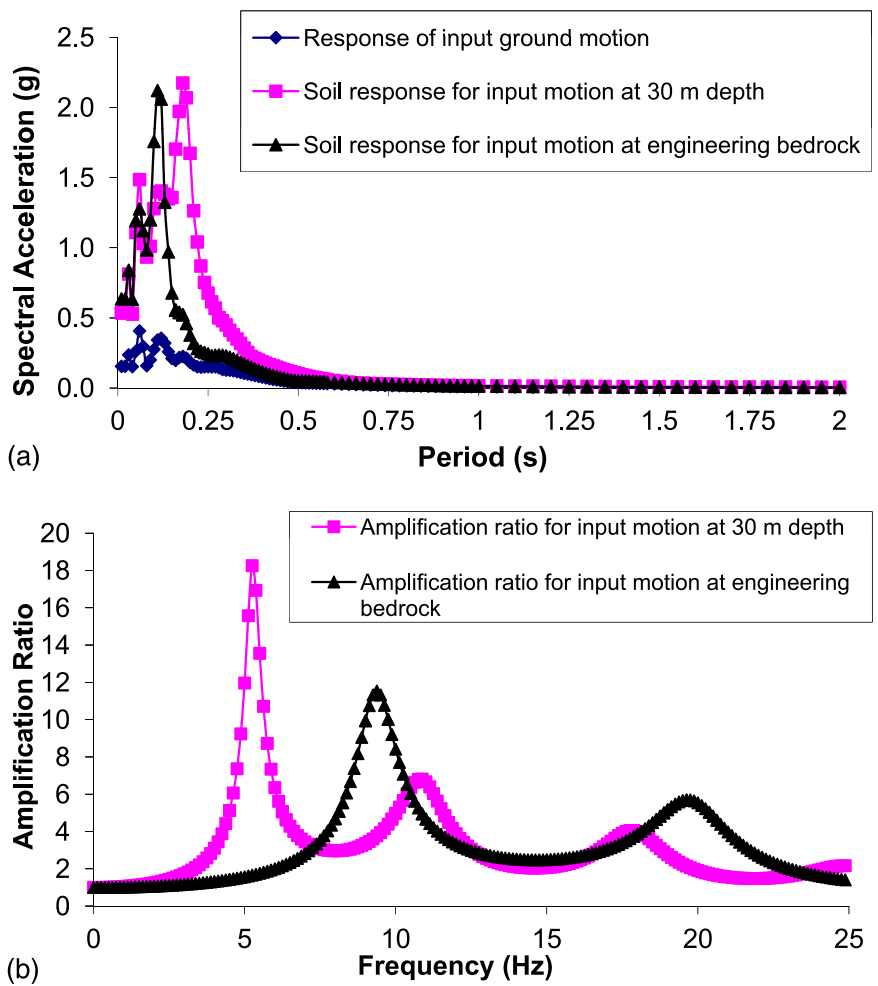

Fig. 15. (a) Response spectrum for SWVP3 when synthetic ground motion is considered as input motion at 30-m depth and at engineeringrock level; (b) amplification ratio for SWVP3 when synthetic ground motion is considered as input motion at 30-m depth and at engineeringrock level

based on the response spectral acceleration and amplification ratio [Figs. 14( $(\mathrm{a}$ and $\mathrm{b})$ ] obtained from site response analyses. The response spectral acceleration and amplification ratio under recorded earthquake ground motion also shows marked difference between the two approaches. It can be observed from Figs. 17( $a$ and b) that for recorded earthquake ground motion, peak response spectral acceleration is higher when input ground motion is applied at engineering rock and peak amplification ratio is slightly greater when input earthquake ground motion is applied at engineering $30-\mathrm{m}$ depth. However, the peak amplification ratios for both simulated earthquake ground motion and recorded earthquake ground motion are similar. Although the response spectral accelerations for SWVP3 under simulated earthquake records are the same when input earthquake ground motion is applied at $30-\mathrm{m}$ depth of soil layers and at engineering rock, the amplification factors are different [Figs. 15 ( $a$ and b)]. It is noted that the site is classified as Site Class B, based on the recommendation of the IBC (ICC 2006) and NEHRP (BSSC 2001). Hence, no site factor is recommended in the IBC (ICC 2006) and NEHRP (BSSC 2001) to obtain soil response spectra from response spectra at bedrock. It is apparent that significant amplification occurs in the period range of engineering interests [Figs. 15(a and b)]. Similar observations have also been obtained from the site response analysis under recorded earthquake ground motion at Chamoli [Figs. 18(a and b)] except that response spectral acceleration is even higher when earthquake ground motion is applied at 30-m depth. Based on average shear wave velocity up to engineering rock, the site is classified as Site Class C. By closer observation of the response spectra and amplification factor, this appears to be a reasonable estimate.
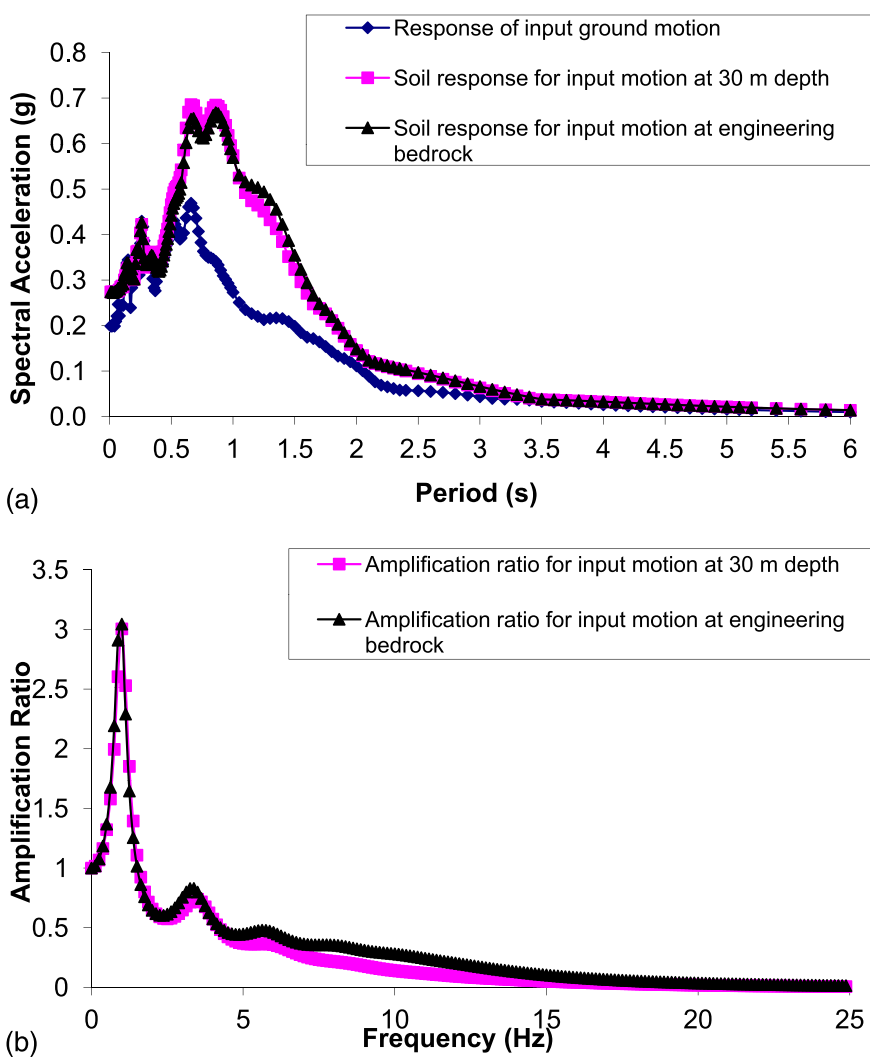

Fig. 16. (a) Response spectrum for SWVP1 when recorded earthquake ground motion at Chamoli is considered as input motion at 30-m depth and at engineering-rock level; (b) amplification ratio for SWVP1 when recorded earthquake ground motion at Chamoli is considered as input motion at 30-m depth and at engineering-rock level

From the foregoing explanation, it appears appropriate to define site classes based on the depth of engineering bedrock and hence the depth of soil columns among other parameters. However, this does not constitute any criticism to the current specifications of site response spectrum or site factors in the IBC (ICC 2006) and NEHRP (BSSC 2001), which have been developed based on regression analyses of a large number of recorded ground motions at both bedrock level and soil surface. These observations simply point out that adopting a site classification scheme based on the IBC (ICC 2006) and NEHRP (BSSC 2001) may not provide the correct conservative response spectra, especially for shallow soil sites where a distinct soil-bedrock interface can be found within $30 \mathrm{~m}$. It has been noted that the IBC (ICC 2006) and NEHRP (BSSC 2001) allow for site-specific site response studies if the generalized site classification and site amplification coefficients are judged to be inadequate for a specific site.

\section{Conclusions}

Seismic site classification systems specified in major seismic design codes are based on the recommendations of the IBC (ICC 2006) and NEHRP (BSSC 2001) considering average shear wave velocity (SWV) of top 30-m (or 20-m) soil layers. The site classification system in the IBC (ICC 2006) and NEHRP (BSSC 2001) is based on the regression analyses of recorded earthquake ground motions in the United States where soil layers may extend up to several hundred meters before reaching a soil-bedrock interface. Such a classification system may not be suitable for regions where 

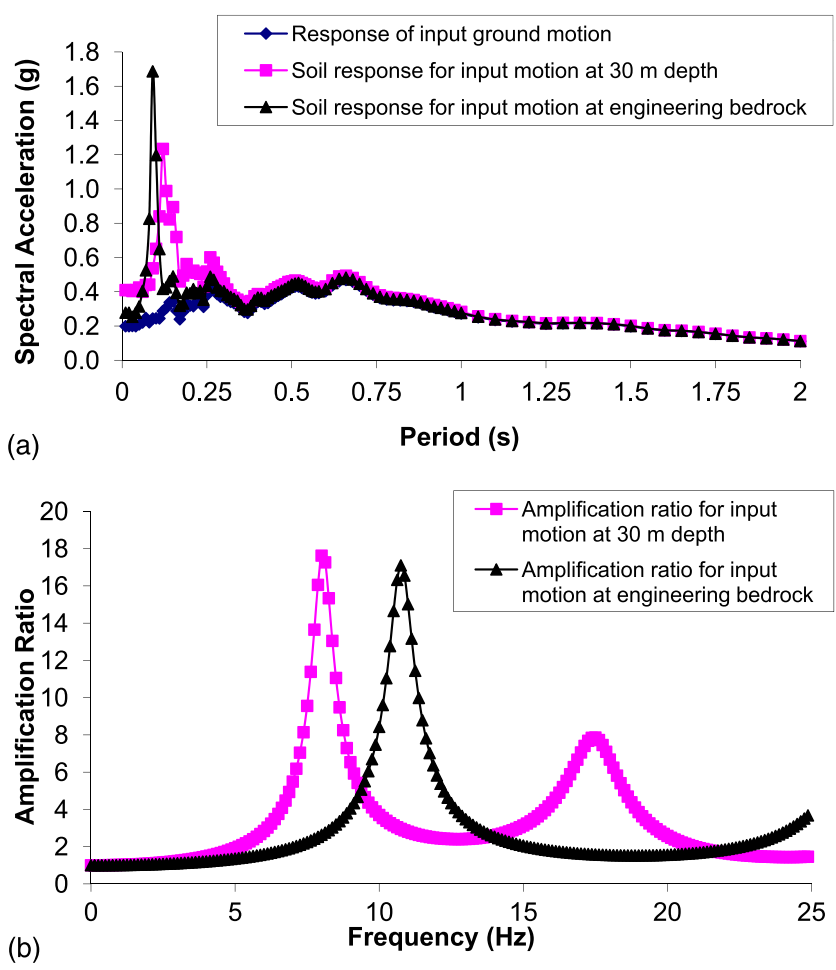

Fig. 17. (a) Response spectrum for SWVP2 when recorded earthquake ground motion at Chamoli is considered as input motion at 30-m depth and at engineering-rock level; (b) amplification ratio for SWVP2 when recorded earthquake ground motion at Chamoli is considered as input motion at 30-m depth and at engineering-rock level
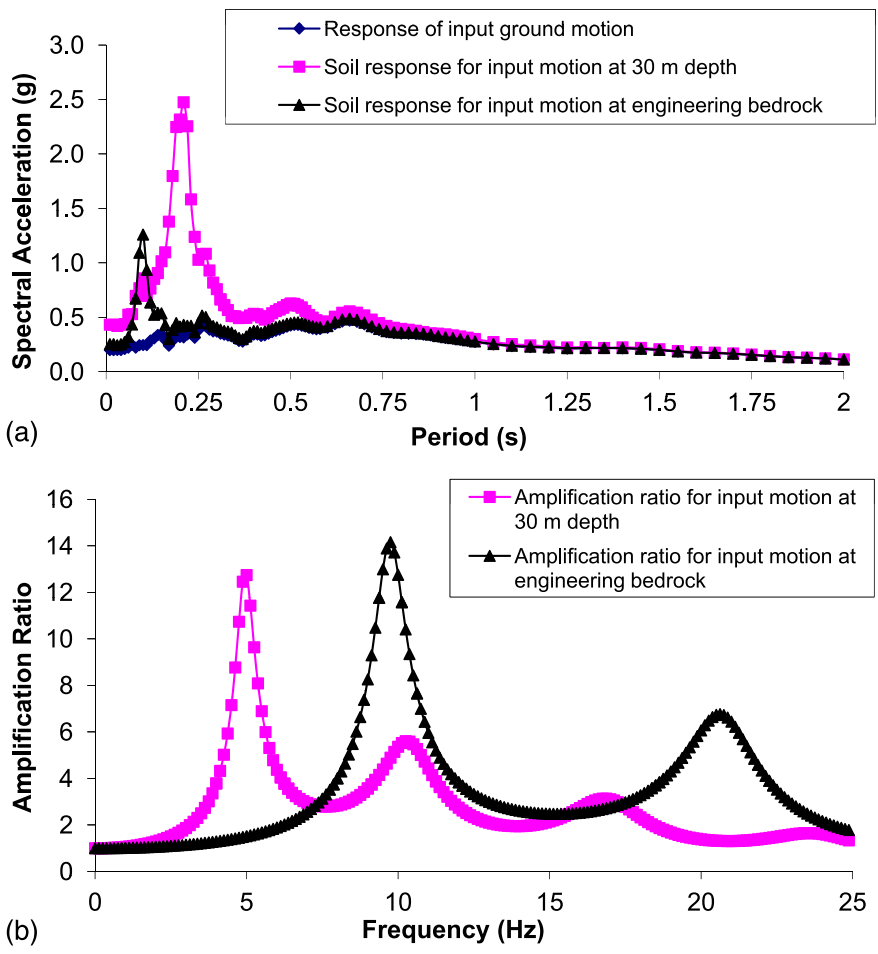

Fig. 18. (a) Response spectrum for SWVP3 when recorded earthquake ground motion at Chamoli is considered as input motion at 30-m depth and at engineering-rock level; (b) amplification ratio for SWVP3 when recorded earthquake ground motion at Chamoli is considered as input motion at 30-m depth and at engineering-rock level a distinct soil-bedrock interface can be found even several meters below the soil surface.

It has been observed, based on the studies of a large number of soil columns in Australia, China, and India, that when engineering rock (SWV $>700 \pm 60 \mathrm{~m} / \mathrm{s})$ depths are shallow, the site classification approaches adopted in the design codes represent stiffer soil columns.

Site response analyses carried out in this study indicate that site amplification factors (short and long period) suggested in the IBC (ICC 2006) and NEHRP (BSSC 2001) may underestimate response spectral ordinates. It is noted that such observation does not constitute any criticism to the current specifications of site response spectrum in the IBC (ICC 2006) and NEHRP (BSSC 2001); these simply point out that adopting a site classification scheme based on the IBC (ICC 2006) and NEHRP (BSSC 2001) may not provide sufficiently conservative response spectra for soil sites at shallow bedrock regions, where a distinct soil-bedrock interface can be found within $30 \mathrm{~m}$.

A new site classification scheme based on the depth of engineering rock has been proposed in this paper. Using one-dimensional site response analyses, a site classification system based on engineeringrock depth was shown to be more representative of the soil columns in shallow bedrock regions. It is noted that a large number of analyses are warranted to propose site factors for site classes based on engineering-rock depth.

\section{Acknowledgments}

The authors gratefully acknowledge the financial support provided to the first author by Seismology Division, Ministry of Earth Sciences, Government of India for the project titled "Site Response Studies Using Strong Motion Accelerographs" (Ref. No. MoES/P.O. (Seismo)/1(20)/2008).

\section{References}

Anbazhagan, P., Basavaraj, S., and Premalatha, K. V. (2011a). "Liquefaction hazard mapping of Chennai using SPT data." Int. J. Earth Sci. Eng., 4(2), 223-232.

Anbazhagan, P., Parihar, A., and Rashmi, H. N. (2011b). "Amplification based on shear wave velocity for seismic zonation: Comparison of empirical relations and site response results for shallow engineering bedrock sites." Geomech. Eng., 3(3), 189-206.

Anbazhagan, P., Parihar, A., and Rashmi, H. N. (2012). "Review of correlations between SPT-N and shear modulus: A new correlation applicable to any region." Soil. Dyn. Earthq. Eng., 36(18), 52-69.

Anbazhagan, P., and Sitharam, T. G. (2008a). "Seismic microzonation of Bangalore." J. Earth Syst. Sci., 117(S2), 833-852.

Anbazhagan, P., and Sitharam, T. G. (2008b). "Site characterization and site response studies using shear wave velocity." J. Seismol. Earthq. Eng., 10(2), 53-67.

Anbazhagan, P., and Sitharam, T. G. (2009a). "Estimation of ground response parameters and comparison with field measurements." Indian Geotech. J., 39(3), 245-270.

Anbazhagan, P., and Sitharam, T. G. (2009b). "Spatial variability of the weathered and engineering bedrock using multichannel analysis of surface wave survey." Pure Appl. Geophys., 166(3), 409-428.

Anbazhagan, P., and Sitharam, T. G. (2010). "Relationship between low strain shear modulus and standard penetration test ' $\mathrm{N}$ ' values." ASTM Geotech. Test. J., 33(2), 150-164.

Anbazhagan, P., Sitharam, T. G., and Vipin, K. S. (2009). "Site classification and estimation of surface level seismic hazard using geophysical data and probabilistic approach." J. Appl. Geophys., 68(2), 219-230. 
Anbazhagan, P., Thingbaijam, K. K. S., Nath, S. K., Narendara Kumar, J. N., and Sitharam, T. G. (2010). "Multi-criteria seismic hazard evaluation for Bangalore City, India." J. Asian Earth Sci., 38(5), 186-198.

Atkinson, G. M., and Boore, D. M. (1995). "Ground-motion relations for eastern North America." Bull. Seismol. Soc. Am., 85(1), 17-30.

Boominathan, A. (2004). "Seismic site characterization for nuclear structures and power plants." Curr. Sci., 87(10), 1388-1397.

Boominathan, A., Dodagoudar, G. R., Suganthi, A., and Uma Maheswari, R. (2008). "Seismic hazard assessment of Chennai city considering local site effects." J. Earth Syst. Sci., 117(S2), 853-863.

Boore, D. M. (1983). "Stochastic simulation of high-frequency ground motions based on seismological models of the radiated spectra." Bull. Seismol. Soc. Am., 73(6), 1865-1894.

Boore, D. M. (2003). "Simulation of ground motion using the stochastic method." Pure Appl. Geophys., 160(3-4), 635-675.

Boore, D. M. (2004). "Estimating $V_{s}$ (30) (or NEHRP site classes) from shallow velocity models (depth $<30$ m)." Bull. Seismol. Soc. Am., 94(2), 591-597.

Borcherdt, R. D. (1994). "Estimates of site-dependent response spectra for design (methodology and justification)." Earthq. Spectra, 10(4), 617-653.

Building Seismic Safety Council (BSSC). (2001). "NEHRP recommended provisions for seismic regulations for new buildings and other structures, 2000 Ed. Part 1: Provisions." Rep. No. FEMA 368, FEMA, Washington, DC.

Bureau of Indian Standards (BIS). (2002). "Indian standard criteria for earthquake resistant design of structures. Part $1-$ General provisions and buildings.” BIS 1983, New Delhi, India.

Chandler, A. M., Lam, N. T. K., and Sheikh, M. N. (2002). "Response spectrum predictions for potential near-field and far-field earthquakes affecting Hong Kong: Soil sites.” Soil. Dyn. Earthq. Eng., 22(6), 419-440.

China Net for Engineering Construction Standardization. (2010). "Code for seismic design of buildings." GB 50011-2010, China Building Industry Press, Beijing.

Collins, C., Kayen, R., Carkin, B., Allen, T., Cummins, P. and McPherson, A. (2006). "Shear wave velocity measurement at Australian ground motion seismometer sites by the spectral analysis of surface waves (SASW) method." Proc., Earthquake Engineering in Australia, Australian Earthquake Engineering Society, Canberra, Australia, 173-178.

Crouse, C. B., and McGuire, J. W. (1996). "Site response studies for purpose of revising NEHRP seismic provisions." Earthq. Spectra, 12(3), 407-439.

Hasancebi, N., and Ulusay, R. (2006). "Evaluation of site amplification and site period using different methods for an earthquake-prone settlement in western Turkey.” Eng. Geol., 87(1), 85-104.

Hwang, H., and Huo, J. R. (1997). "Attenuation relations of ground motion for rock and soil sites in the eastern United States." Soil. Dyn. Earthq. Eng., 16(6), 363-372.

Hwang, J. H., Yang, C. W., and Juang, D. S. (2004). "A practical reliabilitybased method for assessing soil liquefaction potential." Soil. Dyn. Earthq. Eng., 24(9), 761-770.

Institution of Engineers Australia (IEA). (1990). Newcastle earthquake study, Institution of Engineers Australia, Barton, Australia.

International Code Council (ICC). (2006). International building code, 5th Ed., Falls Church, VA.

Kokusho, T. (2008). "Site amplification for seismic zonation in urban areas based on vertical array records." Proc., Int. Conf. Development of Urban Areas and Geotechnical Engineering, Vol. 1, NPO GeoreconstructionFundament Project, St. Petersburg, Russia, 67-80.

Kokusho, T., and Sato, K. (2008). "Surface-to-base amplification evaluated from KiK-net vertical array strongmotion records." Soil Dyn. Earthquake Eng., 28(9), 707-716.
Lee, V. W., Trifunac, M. D., Todorovska, M., and Novikova, E. I. (1995). "Empirical equations describing attenuation of peaks of strong ground motion, in terms of magnitude, distance, path effects and site conditions." Rep. No. CE 95-02, Dept. of Civil Engineering, Univ. of Southern California, Los Angeles.

Ordonez, G. A. (2011). User's manual for SHAKE 2000: A computer program for the 1-D analysis of geotechnical earthquake engineering problems, GeoMotions, Washington, DC.

Pappin, J. W., Koo, R. C. H., Free, M. W., Tsang, H. H., and Lam, N. T. K. (2008). "Evaluation of site effects in Hong Kong." Electr. J. Struct. Eng., 8, 64-76.

Raghu Kanth, S. T. G., and Iyengar, R. N. (2007). "Estimation of seismic spectral acceleration in peninsular India." J. Earth Syst. Sci., 116(3), 199-214.

Roca, A., Oliveira, C. S., Ansal, A., and Figueras, S. (2006). "Local site effects and microzonation." Assessing and managing earthquake risk, C. S. Oliveira, A. Roca, and X. Goula, eds., Springer, Amsterdam, Netherlands, 67-89.

Rodriguez-Marek, A. R., Bray, J. D., and Abrahamson, N. A. (2001). "An empirical geotechnical seismic site response procedure." Earthq. Spectra, 17(1), 65-87.

Schnabel, P. B. (1973). "Effects of local geology and distance from source on earthquake ground motion." Ph.D. thesis, Univ. of California, Berkeley, CA.

Schnabel, P. B., Lysmer, J., and Seed, H. B. (1972). "SHAKE: A computer program for earthquake response analysis of horizontally layered sites." Rep. No. UCB/EERC-72/12:102, Earthquake Engineering Research Center, Univ. of California, Berkeley, CA.

Seed, H. B., and Idriss, I. M. (1970). "Soil moduli and damping factors for dynamic response analyses." Rep. No. EERC-70/10, Earthquake Engineering Research Center, Univ. of California, Berkeley, CA.

Seed, H. B., Whitman, R. V., Dezfulian, H., Dobry, R., and Idriss, I. M. (1972). "Soil conditions and building damage in 1967 Caracas earthquake." J. Soil Mech. and Found. Div., 98(8), 787-806.

Shima, E. (1978). "Seismic microzonation map of Tokyo." Proc., 2nd Int. Conf. on Microzonation for Safer Construction-Research and Application, Vol. I, National Science Foundation, San Francisco, CA, 433443.

Shrikhande, M. (2001). Atlas of Indian strong motion records (CD-ROM), IIT Roorkee, Uttarakhand, India.

Sitharam, T. G., and Anbazhagan, P. (2007). "Seismic hazard analysis for Bangalore region.” J. Natural Hazards, 40(2), 261-278.

Sitharam, T. G., and Anbazhagan, P. (2008). "Seismic microzonation: Principles, practices and experiments." EJGE Special Vol. Bouquet 08. 〈http://www.ejge.com/Bouquet08/Preface.htm〉 (Jan. 25, 2011).

Song, X., Gu, H., Liu, J., and Zhang, X. (2007). "Estimation of shallow subsurface shear-wave velocity by inverting fundamental and highermode Rayleigh waves." Soil. Dyn. Earthquake Eng., 27(7), 599-607.

Standards Australia. (2007). "Structural design actions - earthquake actions in Australia." AS 1170.4-2007, Sydney, Australia.

Tsang, H. H., Chandler, A. M., and Lam, N. T. K. (2006). "Estimating nonlinear site response by single period approximation." Earthquake Eng. Struct. Dynam., 35(9), 1053-1076.

Uma Maheswari, R., Boominathan, A., and Dodagoudar, G. R. (2008). "Development of empirical correlation between shear wave velocity and standard penetration resistance in soils of Chennai City." Proc., 14th World Conf. on Earthquake Engineering, Chinese Association of Earthquake Engineering, Beijing, 8. 